\title{
graditeljsko nasljeđe
}

Izvorni znanstveni rad

UDK 726.54 : 04/99 (497.5 Novo Mjesto) "13" - "15"

Primljeno 2017-12-21

Prihvaćeno za tisak 2018-01-09

\section{KAPELA SV. PETRA U NOVOM MJESTU}

\author{
(Dvadeset godina poslije)
}

Ivan Srša, Zagreb

\section{Sažetak}

U tekstu se razmatraju prva dva stoljeća povijesti Novog Mjesta, kapele i njezinih pokrovitelja, od utemeljenja do obnove početkom 16. stoljeća (1302. - 1502.). Analiziraju se geodetskim mjerenjima utvrđeni položaji uzdužnih osi u kapeli (os svetišta i os broda) i pomoću njihovih azimuta datira se njezino utemeljenje. Sveto usmjerenje kapele i njezin izvorni titular dovode do zaključka da je crkva utemeljena 1302. i posvećena dominikanskom redovniku sv. Petru mučeniku. Kapela sv. Petra utemeljena je u doba Ladislava Rakovečkog koji je sjeverozapadni zid broda dao oslikati prizorima iz ciklusa Legende o sv. Ladislavu, posvećenih njegovu zaštitniku. Pored njih u kapeli je fragmentarno sačuvano $i$ više slojeva zidnih slika iz 14., 15. i 16. stoljeća, među kojima su najvrjednije scene Majke milosrda i Jeseova stabla na trijumfalnom luku, te Sveto lice iz Luccae i apostoli na zidovima svetišta.

Ključne riječi: Novo Mjesto; Kapela sv. Petra; srednji vijek; arhitektura; zidne slike

\section{UVOD}

Godine 1997. Hrvatski restauratorski zavod (HRZ) započeo je radove u kapeli sv. Petra u Novom Mjestu istraživanjem arhitekture i zidnih slika. Uz financiranje Ministarstva kulture Hrvatske i nadzor Konzervatorskog odjela u Zagrebu, od 1997. do 2017. pored restauratorskih radova na zidnim slikama i na kamenu, HRZ kontinuirano projektira, organizira i nadzire sve građevinske i obrtničke radove koji se izvode u kapeli. ${ }^{1}$

${ }^{1}$ Jednim dijelom rezultati istraživanja su objavljeni, a preostali su pohranjeni u izvještajima pohranjenima u arhivu HRZ-u, Konzervatorskom odjelu u Zagrebu i Župnom uredu u Sv. Ivanu Zelini: a) "Konzervatorsko- restauratorski radovi na zidnim slikama u Lovčiću i Novom Mjestu" 
Crkva sv. Petra u Novom Mjestu danas je područna kapela župne crkve sv. Ivana Krstitelja u Sv. Ivanu Zelina. ${ }^{2}$ Njezino kratko četvrtasto svetište presvođeno je križno-rebrastim svodom, a prostrani brod nadvišen je novim drvenim stropom. Uz sjeverozapadni zid svetišta na temeljima srednjovjekovne podignuta je nova sakristija četvrtasta tlocrta, a uz jugozapadni zid broda rekonstruirana je empora. Svetište osvjetljavaju izvorni prozor na sjeveroistočnom i rekonstruirani prozor na jugoistočnom zidu, a brod osvjetljavaju prozor empore i tri rekonstruirana prozora na jugoistočnom zidu, te rekonstruirana bifora na pročelju. $\mathrm{Na}$ osnovu manjih izvornih fragmenta na pročelju broda rekonstruirani su jednostavan kameni portal i drveni tornjić nad krovištem, koje je u cijelosti obnovljeno. Do završetka konzervatorsko-restauratorskih radova od većih i financijski zahtjevnijih zahvata ostalo je žbukanje pročelja i opremanje unutrašnjosti.

\section{NOVO MJESTO I ŽUPA U 14. I 15. STOLJEĆU}

\section{Novo Mjesto}

Najstariji izravni poznati spomen Novog Mjesta datira u godinu 1409. (Novoloco), ${ }^{3}$ to ime mjesta ustalilo se u kroatiziranom obliku sve do danas. Mađarizirana inačica imena najprije se javlja poistovjećivanjem mjesta s titularom župe. Mjesto Sveti Petar (Sz. Peter) spominje se u ispravama od 1429. i tijekom tridesetih godina 15. st., u doba kralja Žigmunda (1387.-1437.) ${ }^{4}$ i bana Hermana Celjskog (1423.-1435.) ${ }^{5}$ odnosno, potkraj biskupstva Ivana Albena na

Vijesti muzealaca i konzervatora, br. 4., 1997.; b) "Kapela sv. Petra u Novom Mjestu”. Kaj, br. 4/5. Zagreb, 1998. c) "Kapela Sv. Petra u Novom Mjestu (Sažetak)" u Sveti Ivan Zelina, lipanj 2000.; d) "Jeseovo stablo", u kapeli sv. Petra u Novom Mjestu. U: Sv. Ivan Zelina i zelinski kraj u prošlosti. Zbornik radova. Zagreb - Sv. Ivan Zelina, 2003.; e) "Zidni oslici u lađi crkve sv. Petra u Novom Mjestu", u Templari i njihovo naslijeđe (800 godina od dolaska templara na zemlju sv. Martina. Muzej Sv. Ivan Zelina. Listopad, 2009.

${ }^{2}$ Sv. Ivan Zelina, župa sv. Ivana Krstitelja. http://www.zupa-svivanakrstitelja.hr/2-zupa/6-kapele (pristupljeno 21.06.2017.)

${ }^{3}$ Muzej Zelina, Inv. br. PA-P-05. - Dobronić, Ljelja, Po starom Moravču. Zagreb, 1979., str. 57. 61.; - Houška, Mladen, Pažić, Janko, Dragija Stjepan i Houška, Jadranka (1994.): Zelinska kronika, Sv. Ivan Zelina, 1994., str. 36

${ }^{4}$ Stipišić, Jakov i Šamšalović, Miljen (1959.), "Isprave u arhivu Jugoslavenske akademije (Inventar)". Historijski zbornik Instituta Jugoslavenske akademije, vol. 2./1959., str. 368 (1777 D-IX89). - 21. IX. 1429. Sigismundus rex Georgio et Nicolao, filiis Francisci de Rakonok alias de Sz. Peter, ac Nicolao et Georgio, filiis Emerici de Bykzaad, pro multis servitiis ius gladii confert.“"

${ }^{5}$ Stipišić, Jakov i Šamšalović, Miljen (1959.), str. 372.(1836 D-X-75), - “3.II. 1433. Hermannus banus capitulo Zagrabiensi praecipit, ut Nicolaum et Georgium, filios Francisci de Zenthpeter, qui contradictione impediverunt, ne Elisabeth, uxor Georgii de Bathyna, in dominio possessionum Zenth-Clara et Chehy statueretur." 
čelu zagrebačke biskupije (1421. - 1433.). ${ }^{6}$ Dvojno mađarizirano ime posjeda Novo Mjesto-Sveti Petar (Wyhel-Zenth Peter) javlja se u četrdesetim godinama 15. stoljeća. ${ }^{7}$ U doba grofova Fridrika II. i Ulrika II., Juraj, sin Franje de ZenthPeter, traži godine 1438. pravdu pred čazmanskim kaptolom zbog posjeda Sveti Petar i susjednih sela. ${ }^{8}$

Između godine 1446. i 1450., u doba biskupstva Benedikta de Zolio ${ }^{9}$ Novo Mjesto javlja se zakratko u svom prvotnom latinskom obliku (Novo loco) ${ }^{10}$ no, u drugoj polovici tog stoljeća ipak prevlada njegova mađarizirana inačica imena (Wyhel), ${ }^{11}$ koja opstaje i tijekom posjedovanja Petra Bisaškoga (umro 1478.). ${ }^{12}$ Nedugo nakon Petrove smrti Novo Mjesto se navodi u latinskom (Novo loco), a $u$ mađariziranom obliku kao dva odvojena posjeda: Wyhel i Zenthpeter. ${ }^{13}$

\section{Župa sv. Petra u Novom Mjestu}

U popisu župa zagrebačke biskupije iz godine 1334. župa u Novom Mjestu se ne spominje. ${ }^{14}$ Među dosad poznatim povijesnim izvorima u Novom Mjestu župa se navodi tek potkraj prvog desetljeća 15. stoljeća, o tome svjedoči spomenuta isprava sastavljena u Zagrebu 1. kolovoza 1409. U njoj se pored župnika iz (Donje) Zeline, Moravča (Sv. Ivan Zelina),

${ }^{6}$ Zagrebačka nadbiskupija. Ivan Alben (1421. - 1433.). http://www.zg-nadbiskupija.hr/default. aspx?id=6946 (pristupljeno 16.12.2017.)

${ }^{7}$ Stipišić, Jakov i Šamšalović, Miljen, "Isprave u Arhivu Jugoslavenske akademije". Historijski zbornik Instituta Jugoslavenske akademije, vol. 3./1960., str. 570.-571.(2085 D-XI-30). - 15.VIII. 1446. Juraj, sin Franje de Wyhel-Zenth Peter.

${ }^{8}$ Stipišić, Jakov i Šamšalović, Miljen (1960.), str. 564. (1974 D-X-63). -„Georgius, filius Francisci de Zenth-Peter, Fridricum eiusque fiiium Ulricum et nepotem Hermannum, Ciliae comites, ab occupatione possessionis suae Zenth-Peter et vicinarum villarum coram capitulo Chasmensi iuridice prohibet.“

9 Zagrebačka nadbiskupija. Benedikt de Zolio (1440. - 1453.) http://www.zg-nadbiskupija.hr/ default.aspx?id=6947 (pristupljeno 16.12.2017.)

${ }^{10}$ Stipišić, Jakov i Šamšalović, Miljen (1960.), str. 575. (2154 D-XI-61). - „16.1.1450. Georgio, filio Francisci de Novoloco.."

${ }^{11}$ Stipišić, Jakov i Šamšalović, Miljen (1960.), str. 586. (2336 D-XIII-6). - „14. II. 1457. Ladislaus rex capitulo Zagrabiensi mandat, ut Margaretham, viduam Georgii de Wyhel, ..."

${ }^{12}$ Stipišić, Jakov i Šamšalović, Miljen (1960.), str. 621. (2853 D-XVI-71). - „1.1.1478. Petrus Bykzaad obligationes incolarum possessionis suae Wyhel..."

${ }^{13}$ Stipišić, Jakov i Šamšalović, Miljen (1960.), str. 621. (2856 D-XVI-22). - „8. II. 1478. Johannes de Novo loco prope Bykzaad,... possessiones Bykzad, Wyhel, Zenthpeter, ..."

${ }^{14}$ Rački, Franjo (1872.), "Popis župa zagrebačke biskupije 1334 i 1401 godine”. Starine JAZU, knjiga IV. Zagreb, 1872., str. 220.; Buturac, Josip (1984.), "Popis župa zagrebačke biskupije 1334 i 1501 godine”. Starine JAZU, knjiga 59. Zagreb, 1984., str. 90. 
Bisaga i drugih spominje i župnik Luka iz Novog Mjesta (luca ad Novoloco). Iz navedenog se može zaključiti da je župa u Novom Mjestu osnovana između godina 1334. i 1409., nakon toga je spomenuta i u popisu župa zagrebačke biskupije godine 1501. (Lucas plebanus de Novo loco). ${ }^{15}$ No, ni $\mathrm{u}$ jednom od spomenuta dva izvora ne navodi se njezin titular.

U ispravi od 21. kolovoza 1381. u kojoj se opisuju međe prilikom diobe posjeda Rakovec (possessio Rakounuk), poviše javnog puta koji vodi prema crkvi sv.Petra mučenika (ecclesiam sancti Petri martiris), ${ }^{16}$ bez navođenja imena mjesta spominje se dom Rakovečkih zvan Megech (domo ipsius Megech $^{17}$ ).

U Kalničkomu arhiđakonatu, kojemu su u Srednjem vijeku pripadali i Rakovec i Novo Mjesto, ${ }^{18}$ u popisu župa iz 1334. sv. Petru apostolu bile su posvećene župne crkve u Preseki (ecclesia beati Petri de Preseka), ${ }^{19}$ Sv. Petru Čvrstecu (beati Petri de Chrostuecz) ${ }^{20}$ i Sv. Petru Orehovečkom (sancti Petri in Orehowecz). ${ }^{21}$ Premda je apostol Petar također umro mučeničkom smrću nijedna od navedenih župnih crkvi u titularu ga ne navodi kao mučenika. ${ }^{22}$

S obzirom na to može se pretpostaviti da se titular crkve spomenute u ispravi iz 1381. i posvećene sv. Petru mučeniku (Petrus Martyr ili Petrus Veronensis) odnosi upravo na današnju kapelu u Novom Mjestu. Sveti Petar mučenik bio je redovnik dominikanskog reda i inkvizitor (1206. 1252.), kojega je godinu dana nakon njegove mučeničke smrti kanonizirao 25. ožujka 1253. papa Innocent IV. (1243. - 1254.). ${ }^{23}$

\footnotetext{
${ }^{15}$ Buturac, Josip, (1984.), str. 90.

${ }^{16}$ Diplomatički zbornik kraljevine Hrvatske, Dalmacije i Slavonije (DZ), Zagreb, 1976., XVI, str. 209. i 246.

${ }^{17}$ Ime njihova doma (Megech) blisko je mađarskoj riječi megég (spaliti).

${ }^{18}$ Prema “Općem šematizmu Katoličke crkve u Jugoslaviji, Cerkev v Jugoslaviji 1974." Zagreb, 1975., str. 106- 108., Rakovec (Vrbovečki Rakovec) danas pripada Križevačkom, a Novo Mjesto Zelinskom dekanatu.

${ }^{19}$ Buturac, Josip, (1984.), str. 89.

${ }^{20}$ Buturac, Josip, (1984.), str. 89.

${ }^{21}$ Buturac, Josip, (1984.), str. 88.

${ }^{22}$ U titularu crkve u Preseki 1392. navodi se da je apostol Petar blaženik, ali ne i da je mučenik („...prope ecclesiam beati Petri apostoli in eadem possessione Prezekazenthpeter...“), DZ (1981.), XVII., str. 470-472.

${ }^{23}$ Voragine, Jacobus de, The Golden Legend. I, Princeton, New Jersey, 1995., str. 254. - 266.
} 


\section{VLASNICI NOVOG MJESTA U 14. I 15. STOLJEĆU}

\section{Ladislav Rakovečki i njegovi nasljednici}

Rakovečki su potomci moravečkih župana Abrahama i Nikole. ${ }^{24}$ Tijekom 14. i 15. stoljeća razgranali su se u tri ogranka: jedan sa sjedištem u Rakovcu, drugi u Novom Mjestu i treći u Bisagu. O tome svjedoči isprava iz godine 1446. ${ }^{25}$ : rod iz Rakovca (Anthonium, filium Petri de Rakonok), Novog Mjesta (Georgium, filium Francisci de Wyhel-Zentb-Peter alias de Chechy) i Bisaga (Georgium, filium Emerici de Bykzad).

$\mathrm{U}$ ispravi iz godine 1319. spominju se sinovi Ladislava iz Rakovca (Ladislai de Rakolnuk): Martin, Abram i Nikola, ${ }^{26}$ a godine 1321. potonji se navodi kao vir nobilis magister Nicolaus filius Ladislai de Rakolnuk. ${ }^{27}$ Ladislav (Ladislai, filii Bartholomei de Rakonok) je umro prije godine 1326., jer je te godine njegova supruga navedena kao udovica (viduae Ladislai). ${ }^{28}$ Rakovečki se navode među objavljenim ispravama tijekom čitavog 14. stoljeća ${ }^{29}$, a među posljednjima su one iz $1394 .{ }^{30}$ i $1396 .{ }^{31}$

Posljednji članovi roda Rakovečkih navode se godine 1438.: Tomin sin Petar (filius Thomae de Rakonok) ${ }^{32}$ i godine 1446. Petrov sin Anton (Anthonium, filium Petri de Rakonok). ${ }^{33}$ Nakon te godine Rakovečki se ne spominju. Međutim, ime posjeda koji im je nekoć pripadao navodi se još godine 1457. (possessionis Rakonok). ${ }^{34}$

\footnotetext{
${ }^{24}$ Pajur, Franjo, “Rakovec (Rakonuk) kao središnji posjed okolice”. Kaj, br. 3-4, 2016, str. 87-116.

${ }^{25}$ Stipišić, Jakov i Šamšalović, Miljen (1960.), str. 570.-571. (2085 D-XI-30) i str. 585. (2336 D-XIII-6).

${ }^{26}$ DZ, VIII (1910.), str. 521. - Zelinska kronika (1994.), str. 26.

${ }^{27}$ DZ, IX (1911.), str. 36. i 37.

${ }^{28}$ Stipišić, Jakov i Šamšalović, Miljen (1959.), str. 301. (368 I -d 32, elen. F. 242.) - Regestum documenti suspecti.

${ }^{29}$ DZ, VIII (1910.), str. 460, 465, 521, 556.-559, 572. - DZ, IX (1911.), str. 571. - DZ, X (1912.), str. 10.-11, 16, 423. - DZ, XI (1913.), str. 16, 115, 222.-223, 280, str. 302, 329, 528. - DZ, XV (1934.), str. 407. - DZ, XVI (1976.). str. 407. - DZ, XVII (1981.), str. 5, 245.-248, 470.-472, 598. - DZ, XVIII (1990.), str. 115.-116. (1396.).

${ }^{30}$ DZ, XVII (1981.), str. 598.

${ }^{31}$ DZ, XVIII (1990.), str. 115.-116.

${ }^{32}$ Stipišić, Jakov i Šamšalović, Miljen, (1960.), str. 564.(1974 D-X-63).

${ }^{33}$ Stipišić, Jakov i Šamšalović, Miljen, (1960.), str. 570.-571. (2085 D-XI-30).

${ }^{34}$ Stipišić, Jakov i Šamšalović, Miljen, (1960.), str. 586. (2344 D-XIII-7).
} 
O ogranku Rakovečkih koji je sjedište imao u Novom Mjestu svjedoči isprava iz godine 1429., u kojoj se spominju Juraj i Nikola, sinovi Franje de Rakonok alias de Sz. Peter. ${ }^{35}$ Iz imena mjesta vidljivo je da je u to doba ono (Novoloco) u posjedu plemića Rakovečkih i da je mjesto poistovjećeno s titularom župe (Sz. Peter). Franjini sinovi Nikola i Juraj (de Zenthpeter), zajedno se navode još u godinama $1430 .{ }^{36}$ i 1433 . (Nicolaum et Georgium, filios Francisci de Zenthpeter), ${ }^{37}$ dok se od godine 1438. spominje samo Juraj (Georgius, filius Francisci de Zenth-Peter). ${ }^{38}$ Čini se da Juraj i Margareta $^{39}$ ili nisu imali nasljednika ili je zarana umro jer je Novo Mjesto (Wyhel) dospjelo u ruke trećega roda plemića Rakovečkih, onoga koji je svoje sjedište imao u Bisagu.

U dosad poznatim izvorima pridjev Bisaški ${ }^{40}$ najprije se veže uz magistra Mirka, sina Mikeca iz Bisaga (Emericus filius Mykech de Bykzad), koji se spominje u ispravi iz godine 1389. ${ }^{41}$ Mykec je mađarska inačica (deminutiv) imena Nikola (Mikloš, ${ }^{42} M_{i k o^{43}}$ ), na što upozorava i ime Emerikova sina Nikole koji je ime dobio po djedu (vir nobilis magister Nicolaus filius Ladislai de Rakolnuk.). Emerikovi sinovi Nikola i Juraj zajedno s istoimenim sinovima Franje iz Novog Mjesta godine 1429. dobivaju od kralja Žigmunda "pravo mača ( jus gladii). ${ }^{44}$ Iduće godine njima i sinovima Franje iz Novog Mjesta kralj daruje dvadesetak posjeda. ${ }^{45}$ Juraj Bisaški

${ }^{35}$ Stipišić, Jakov i Šamšalović, Miljen, (1959.), str. 368. (1777 D-IX-89).
${ }^{36}$ Stipišić, Jakov i Šamšalović, Miljen, (1959.), str. 369. (1796 D-IX-78).
${ }^{37}$ Stipišić, Jakov i Šamšalović, Miljen, (1959.), str. 372. (1836 D-X-75).
${ }^{38}$ Stipišić, Jakov i Šamšalović, Miljen (1960.), str. 564. (1974 D-X-63).
${ }^{39}$ Stipišić, Jakov i Šamšalović, Miljen (1960.), str. 586. (2336 D-XIII-6): (14. II. 1457. "Ladislaus rex capitulo Zagrabiensi mandat, ut Margaretham, viduam Georgii de Wyhel....”

${ }^{40}$ Hrvatski biografski leksikon (1998.), BISAŠKI. (Nemeth, Krešimir, 1983.). - Desző Csánki (1893.), Körösmegye a XV-ik században. Budapest, 1893., str. 6. - Josip Adamček, Agrarni odnosi u Hrvatskoj od sredine XV do kraja XVII stoljeća. Zagreb, 1980., str. 94.

${ }^{41}$ DZ, XVII (1981.), str. 188. i 192.

${ }^{42}$ Miklós: Hungarian form of Greek Nikolaos meaning "victor of the people." Web stranica: http://www.20000-names.com/male hungarian names.htm (pristupljeno 10.7.2017.)

43 Mik(o) - Nikola (lat. Nicolaus) - Frančić Anđela, Međimurska prezimena. Zagreb, 2002., str. 393.

${ }^{44}$ Stipišić, Jakov i Šamšalović, Miljen (1959.), str. 368. (1777 D-IX-89).

${ }^{45}$ Stipišić, Jakov i Šamšalović, Miljen (1959.), str. 369. - (1793 D-IX-78.). - 7. VI. 1430. „Sigismundus rex capitulo Chasmensi mandat, ut Nicolaum et Georgium, filios Emerici de Bykzaad, ac Nicolaum et Georgium, pronepotes comitis Abrabae de Zenthpeter alias de Chehy, in dominium possessionum Bykzaad, Radowisschye, Dolghyworch, Prylak, Tharnasowcz. Brezthech, Myrkowcz, 
godine 1438. bio je viceban (Georgius de Bykzad vicebanus). ${ }^{46}$

Nakon godine 1447. ${ }^{47}$ Juraj Bisaški spominje se još u veljači 1457., ${ }^{48}$ umro je između veljače i svibnja iste godine. U svibnju 1457. njegovi potomci od kralja Ladislava traže posjede Rakovečkih koje je nakon smrti grofa Ulrika II. Celjskog ( $† 1456$.$) prisvojio srpski despot Lazar, brat$ Katarine Celjske. ${ }^{49}$

Petar Bisaški (Petrus, filius qd. Georgii de Bykzaad) u posjed Novog Mjesta došao je nakon smrti Margarete (viduam Georgii de Wyhel), svakako prije godine $1474 .^{50}$ i godine 1478 . kad izrijekom spominje Novo Mjesto kao svoj posjed (possessionis suae Wyhel). ${ }^{51}$ Petar i njegova supruga Sophia (vidua Petri de Bykzad) nisu imali nasljednika pa još godine 1474. Petar daruje svoje posjede sestri Ani, udovici Nikole Kaštelanovića (vidua Nicolai Castellan de Zenthlelek). ${ }^{52}$

\section{CRKVA SV. PETRA U NOVOM MJESTU}

\section{Zemljopisni položaj Novog Mjesta i Sveto usmjerenje}

Ortwin Feustel navodi da su brodovi njemačkih srednjovjekovnih crkava usmjeravani Sunčevim izlaskom na blagdan sveca kojemu su bile posvećene, a otklon azimuta i do $25^{\circ}$ prema sjeveroistoku $\left(65^{\circ}\right)$ ili jugoistoku $\left(115^{\circ}\right) \mathrm{u}$ odnosu na zemljopisni istok $\left(90^{\circ} \mathrm{E}\right)$, naziva sveto usmjerenje (Holy Alignment.). ${ }^{53}$

Keleminowcz, Vydowcz, Horwatinowcz, Praschnyak, Trobyncz, Zenthpeter, Krethafalwa, Kemen, Nowak, Zaprodye, Chehy, Ebres atque vadi in fluvio Ferenzrewe introducat."

${ }^{46}$ Stipišić, Jakov i Šamšalović, Miljen (1960.), str. 563. (1965 D-X-60).

${ }^{47}$ Stipišić, Jakov i Šamšalović, Miljen (1960.), str. 571. (2099 D-XI-32).

${ }^{48}$ Kukuljević Sakcinski, Ivan (1862.), Jura regni Croatiae, Dalmatiae et Slavoniae, 1. Zagreb 1862, str. 202.-203.

${ }^{49}$ Stipišić, Jakov i Šamšalović, Miljen (1960.), str. 586. (2344 D-XIII-7). „Martinus presbyter, capellanus Petri, filii qd. Georgii de Bykzaad..."

${ }^{50}$ Stipišić, Jakov i Šamšalović, Miljen (1960.), str. 616. (2777 D i d 12. elen. IV. p. 23)

${ }^{51}$ Stipišić, Jakov i Šamšalović, Miljen (1960.), str. 621.(2853 D-XVI-71.).

${ }^{52}$ Stipišić, Jakov i Šamšalović, Miljen (1960.), str. 611. (2709 D-XV-45.).

${ }^{53}$ Feustel, Ortwin, "The Holy Alignment: Geodesic and Astronomical Fundamentals For Calculating the Adjustment of Medieval Naves". Nexus Network Journal, Vol. 11, No. 1 (2009.), str. 7-21. https://link.springer.com/content/f/10.1007\%2Fs00004-007-0078-2.pdf (pristupljeno 5. 12. 2017.). 


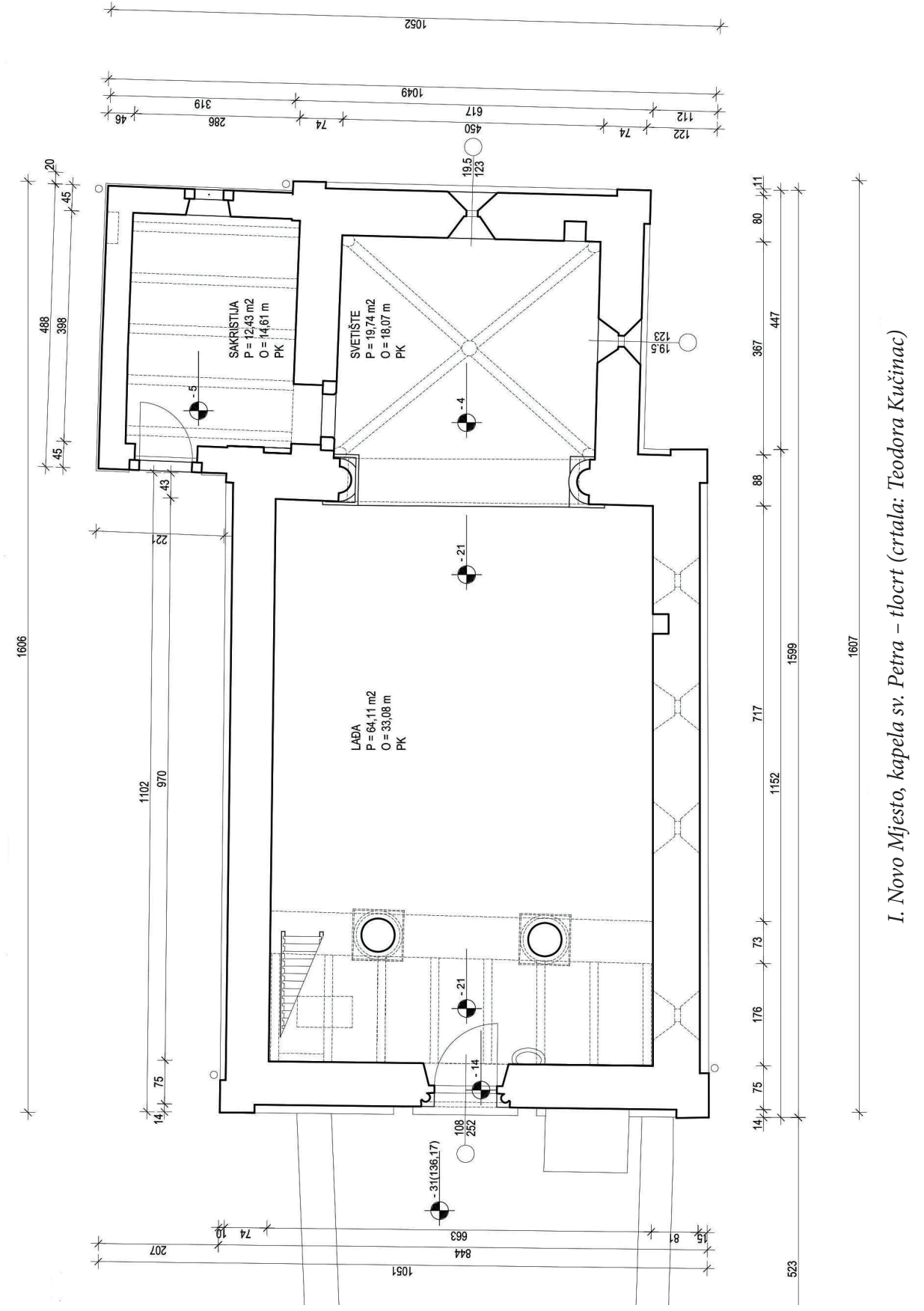


Određivanje svetog usmjerenja broda u kapeli sv. Petra započelo je utvrđivanjem zemljopisnog položaja Novog Mjesta, a potom geodetskim mjerenjima i izračunavanjem odmaka azimuta od zemljopisnog istoka $\left(90^{\circ}\right)$. Novo Mjesto nalazi se na $16^{\circ} 17^{\prime} 15^{\prime \prime}(\mathrm{E})$ zemljopisne dužine $(\lambda)$ i $45^{\circ} 57^{\prime} 13^{\prime \prime}(\mathrm{N})$ zemljopisne širine $(\varphi)$. Za zimskog solsticija Sunce u Novom Mjestu izlazi u 07:34h na azimutu $123^{\circ} 51^{\prime}$ (SE), a za ljetnog solsticija u 05:04h na azimutu 54 $03^{\prime}$ (NE). ${ }^{54} \mathrm{Od}$ zimskog solsticija prema ljetnom solsticiju Sunčev izlazak sve je raniji i sve su manji stupnjevi azimuta na kojemu ono izlazi. Obrnut slijed počinje nakon ljetnog solsticija, Sunce izlazi sve kasnije i na sve većim stupnjevima azimuta.

Geodetskim mjerenjima provedenima u listopadu $2017 .{ }^{55}$ utvrđeno je da azimut svetog usmjerenja broda u Novom Mjestu približno odgovara izlasku Sunca u dane 30. travnja 2017. i 12. kolovoza $2017 .{ }^{56}$ Prvoga od dva navedena dana Sunce

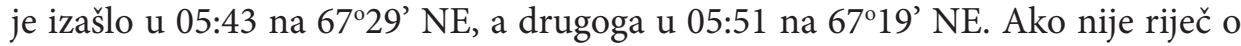
greški nastaloj još prilikom mjerenja i temeljenja crkve, onda os svetišta, zaokrenuta približno za jedan stupanj prema istoku u odnosu na os borda (68 $\left.21^{\prime} 30^{\prime \prime}\right)$, upućuje na još jedan datum. Naime, neke srednjovjekovne crkve i kapele imaju dvije uzdužne osi (os svetišta i os broda) i time dva sveta usmjerenja s međusobnim otklonom od nekoliko stupnjeva, takav primjer je i kapela sv. Petra u Novom Mjestu (crtež I.). ${ }^{57}$

$\mathrm{Na}$ azimutu približno za jedan stupanj većem od onoga u brodu, kojim je određeno sveto usmjerenje svetišta, Sunce je u proljeće i ljeti 2017. izašlo po dva dana zaredom: 28 . i 29 . travnja, te 13 . i 14 . kolovoza. Na azimutu $68^{\circ} 25^{\prime}(\mathrm{NE})$ izašlo je 28. travnja 2017. u 05:47 h, a 14. kolovoza 2017. izašlo je u 05:53 h na azimutu $68^{\circ} 15^{\prime}(\mathrm{NE}) .^{58}$

\section{Pretpostavljeni datum odredivanja Svetog usmjerenja}

Tijekom Srednjeg vijeka u Europi se rabio Julijanski kalendar, a navedeni proljetni datum kojim je određena os broda (30. travnja) za 13. st. (do godine 1299.)

${ }^{54}$ Katedra za satelitsku geodeziju. On line efemeride. http://astrogeo.geoinfo.geof.hr/online efemeride/sunrise sunset/ (pristupljeno 3.3.2017.)

${ }^{55}$ Izmjere je u listopadu obavio gospodin Dubravko Gajski (Geodetski fakultet Sveučilišta u Zagrebu, Katedra za fotogrametriju), kojem se o

vom prilikom iskreno zahvaljujem na njegovu ustupljenom vremenu i pro bono snimanju.

${ }^{56}$ Katedra za satelitsku geodeziju: http://astrogeo.geoinfo.geof.hr/online efemeride/sunrise sunset/ (pristupljeno 27.11.2017.)

${ }^{57}$ Izrazit primjer s odmakom između osi apside i broda ima i kapela sv. Martina iz 13. st. u Lovčiću (Požeška biskupija).

${ }^{58}$ Katedra za satelitsku geodeziju: http://astrogeo.geoinfo.geof.hr/online efemeride/sunrise sunset/ (27.11.2017.) 
računa se kao 23. travnja, a za 14. st. (od 1300. godine) kao 22. travnja. ${ }^{59} \mathrm{U}$ nedjelju 23. travnja u 13. stoljeću dvaput je bio Uskrs i to oba puta u prvoj polovici stoljeća: 1223 . i $1234{ }^{60}$

$\mathrm{U}$ odnosu na tipologiju arhitekture, zidne slike i titular današnje kapele $\mathrm{u}$ Novom Mjestu koja je izvorno bila posvećena sv. Petru mučeniku (ecclesiam sancti Petri martiris ${ }^{61}$ ), te dvije godine nisu uzete u obzir za određivanje datuma usmjerenja i temeljenja crkve u Novom Mjestu, jer je dominikanac Petar mučenik (San Pietro da Verona) svecem proglašen tek 25 . ožujka $1253 .{ }^{62}$

U 14. stoljeću na dan 22. travnja Uskrs je bio četiri puta: 1302., 1375., 1386. i $1397 .{ }^{63}$ Najizgledniji Uskrs, za kojega se moglo odrediti sveto usmjerenje crkve u Novom Mjestu, jest onaj u godini 1302. Dominikanski svetac sv. Petar mučenik usmrćen je 6. travnja 1252., pa godina 1302. upućuje na obilježavanje pedesete obljetnice svečeve smrti. Na takav zaključak navodi i poklapanje azimuta Sunčevog izlaska na horizontu Novog Mjesta 30. travnja 2017. s azimutom 12. kolovoza 2017. Prema julijanskom kalendaru navedeni ljetni datum za 14. stoljeće računa se kao 4 . kolovoz, dan kad se svetkovao sv. Doiminik, osnivač dominikanskog reda. ${ }^{64}$

Dani 28. travnja 2017. i 14. kolovoza 2017. - u kojima je Sunce na horizontu Novog Mjesta izašlo za stupanj većem azimutu od onoga u brodu i kojim je određeno sveto usmjerenje svetišta - za 14. stoljeće računaju se kao 20. travnja i 6. kolovoza. Za proljetnog datuma godine 1302. bio je Veliki petak, a za ljetnog se svetkovalo Preobraženje Kristovo ${ }^{65}$ : „Tada se preobrazi pred njima; lice mu zasja kao sunce, a haljine postadoše bijele kao svjetlo." ${ }^{66}$

Iz navedenog se može zaključiti da sveto usmjerenje broda upućuje na Uskrs godine 1302. a sveto usmjerenje svetišta na Veliki petak iste godine. Azimut svetog usmjerenja broda ukazuje i na moguće podrijetlo kreatora koji je astronomskim proračunom utvrdio poklapanje najvećeg kršćanskog blagdana sa svetkovanjem 2017.)

${ }^{59}$ Calendar converter: http://www.fourmilab.ch/documents/calendar/ (pristupljeno 27. 11.

${ }^{60}$ Cappelli, Adriano, Cronologia Cronografia e Calendario perpetuo, Milano, 2002, 100.

${ }^{61}$ DZ, XVI (1976.), str. 209. i 246.

${ }^{62}$ Voragine, Jacobus de, (1995.), I, str. 254.-266. - Catholic Encyclopaedia. St. Peter of Verona. http://www.newadvent.org/cathen/11773d.htm (pristupljeno 22.2.2017.)

${ }^{63}$ Cappelli, Adriano (2002.), str. 98.

${ }^{64}$ Voragine, Jacobus de, (1995.), II, str. 44.-58. Cappelli, Adriano (2002.), str. 98. - Vetus Martyrologium Romanum: http://www.documentacatholicaomnia.eu/03d/1856-1856, Absens, Vetus_Martyrologium_Romanum,_LT.pdf pristupljeno 5.12.2017.)

${ }^{65}$ Cappelli, Adriaño (2002.), str. 98. i 99.

${ }^{66}$ Biblija, Stari i Novi zavjet, Zagreb 1968. Evanđelje po Mateju, 17:2-8 
sv. Dominika. ${ }^{67}$ Ima li se u vidu da su astronomiji dominikanci pridavali posebnu ozbiljnost $^{68}$ može se pretpostaviti da kreator crkve u Novom Mjestu potječe iz dominikanskog reda.

\section{Zagrebački biskupi početkom 14. stoljeća}

U pretpostavljenoj godini utemeljenja crkve (1302.) na čelu zagrebačke biskupije bio je Michael ${ }^{69}$ (Mihály de genere Bö , 1295. - 1303.). Od godine 1298. čini se da je većinom boravio na kraljevskom dvoru, ${ }^{70}$ a kad je i boravio u Slavoniji svojom biskupijom je Michael uglavnom upravljao iz čazmanskog kaptola. ${ }^{71}$ Zanimljiva isprava s kraja 13 . stoljeća datirana 22. siječnja 1299 . svjedoči da su redovnici čazmanskog dominikanskog samostana bili blisko povezani s tamošnjim kaptolom: „Nos capitulum Chasmensis ecclesie, et fratres Symon nunc subprior et Stephanus lector, ac conventus fratrum Praedicatorum domus loci eiusdem..."72 S Michaelovim nasljednikom na čelu zagrebačke biskupije ta se povezanost nastavila i produbila.

U svom kratkotrajnom mandatu papa Benedikt XI (22. 10. 1303.-7. 7. 1304.), kardinal i prijašnji deveti generalni magistar dominikanskog reda Nikola Bocassini, ${ }^{73}$ na čelo zagrebačke biskupije postavio je 9.12.1303. svoga kapelana, dominikanca Augustina Kažotića. ${ }^{74}$ Kažotić (1303. - 1323.) je također najviše stolovao u Čazmi u kojoj je organizirao svoju kancelariju. ${ }^{75}$ Da je štovao $s v$. Petra mučenika svjedoči činjenica da se dao pokopati u istoimenoj kapeli u samostan-

${ }^{67}$ Sveti Dominik zaštitnik je astronoma i astronomije. Sv. Dominik, patron of astronomers: http://catholicsaints.info/patrons-of-astronomers/ (pristupljeno 27. 11. 2017.) - Voragine, Jacobus de (1995.), II, str. 45.

${ }^{68}$ Šanjek, Franjo (1988.), Crkva i kršćanstvo u Hrvata 1. Zagreb, 1988., str. 289. - Anonimni autor Knjige za pouke novaka (Libellus de instructione noviciorum) „pretpostavlja njezina (astronomije, op. I. S.) otkrića kao sigurna, završna i konačna (!).“

${ }^{69}$ Buturac, Josip, “Zagrebački biskupi i nadbiskupi 1094.-1944.” u: Kulturno-poviestni zbornik Zagrebačke nadbiskupije, Zagreb, 1944. str. 27-28.

${ }^{70}$ Beke, Margit, Esztergomi érszekek 1001-2003. Budapest 2003. 142-145 (Bő nembeli Mihály) - https://en.wikipedia.org/wiki/Michael B\%C5\%91 (5.12.2017.)

${ }^{71}$ CD, (1909.) VII, str. 327 (22.1.1299.), str. 370 (6.3.1300.); CD, (1910.), VIII, str. 7-9. (29.4.1301.), str. 33-34. (6.10.1302.), str. 39-41. (21.12.1302.), str. 54-55.(30.6.1303.).

${ }^{72} \mathrm{CD},(1909),. \mathrm{VII}$, str. 327 (21.1.1299.)

${ }^{73}$ Nicola Boccasini (Benedict XI) elected Pope. https://worldhistoryproject.org/1303/10/22/ nicola-boccasini-benedict-xi-elected-pope (pristupljeno 3.5.2017.

${ }^{74}$ CD, VIII (1910.), str. 60-62. - Buturac, Josip (1944.), str. 28. - 30. - Šanjek, Franjo (1991.), Kršćanstvo na hrvatskom prostoru. Zagreb, 1991., str. 169.-172. - Šanjek, Franjo (2009.). “Kažotić”, u Hrvatski biografski leksikon (HBL).

${ }^{75}$ Klaić, Nada, Zagreb u srednjem vijeku. Zagreb, 1982., str. 495. 
skoj crkvi sv. Dominika u Luceri 3. kolovoza $1323 .^{76}$

U godinama između 1305. i 1314. biskupstvo Augustina Kažotić poklapalo se s papinstvom Klementa V. (5. 6. 1305. - 20. 4. 1314. $)^{77}$ koji je naslijedio papu Benedikta XI. i s nastavkom gradnje i opremanjem crkve sv. Petra mučenika u Novom Mjestu. Posredno o godinama Kažotićeva biskupstva i Klementova papinstva svjedoči i svetkovanje sv. pape Klementa I. u Novom Mjestu još početkom 18. stoljeća (1704.). ${ }^{78}$ Naime, nadbiskup Bordeauxa, Raymond Bertrand de Got, nakon izbora za papu ime Klement V. odabrao je po sv. papi Klementu I. (88.-99.). Njegovo svetkovanje u Novom Mjesto najvjerojatnije je uvedeno još u doba biskupa Kažotića i održalo se sve do 18. stoljeća.

Nakon Kažotićeve smrti na čelu zagrebačke biskupije ponovno je bio imenovan dominikanac, Jakob I. (1322. - 1326.) koji nije boravio u Zagrebu već ga je mijenjao čazmanski prepošt Petar de Incristellis. Njegovo neuspješno biskupstvo okončao je papa Ivan XXII. (1314.-1334.), ${ }^{79}$ koji u Ugarskoj i Slavoniji dominikancima zabranjuje inkviziciju i povjerava ju franjevcima.$^{80}$ Međutim, da time nije znatnije oslabljen utjecaj dominikanaca u srednjovjekovnoj Slavoniji, svjedoči i freska iz posljednje četvrtine 14. stoljeća na sjevernom zidu broda u crkvi sv. Brcka u današnjem Kalniku, koja „prikazuje mučeničku smrt dominikanskog inkvizitora XIII stoljeća, sv. Petra Mučenika iz Verone“. ${ }^{81}$

U doba određivanja svetog usmjerenja Novo Mjesto posjedovala je plemićka obitelj Rakovečki. U prvoj polovici 14. stoljeća u toj se obitelji među ostalima spominju Martinov sin Petar (1332. i 1342.) ${ }^{82}$ i Dominikov sin Tomo (1338. i 1344.). ${ }^{83}$ Nije poznato je li Martinovu sinu Petru nadjenuto ime po dominikanskom svecu, no za Jurjeva sina Petra de Bykzad, ${ }^{84}$ koji je Novo Mjesto (Wyhel) posjedovao u

${ }^{76}$ Dominikanski samostan blaženog Augustina Kažotića u Zagrebu. Bl. Augustin Kažotić u povijesnim zbivanjima - kronološki pregled. http://kazotic.org/index.php/bl-augustin-kazotic (pristupljeno 25.5.2017.)

${ }_{77}$ Pope Clement V. Catholic encyclopaedia. http://www.newadvent.org/cathen/04020a.htm (pristupljeno 3.5.2017.)

${ }^{78}$ Nadbiskupski arhiv u Zagrebu (NAZ). Kanonske vizitacije, Protokol br 130/I., str. 186.

${ }^{79}$ Buturac, Josip (1944.), str. 30. -31.

${ }^{80} \mathrm{CD}$, IX (1911.), str. 348.-349.

${ }^{81}$ Deanović, Ana (1961), “Talijanski slikar na visočini Kalnika”. Peristil, br, Zagreb, 1961. str. 21-28.

${ }^{82}$ CD, X (1912.), 10-11 (10.3.1332.) i XI (1913.), 16 (9.10.1342.) - „...Petrus filius Martini filii Ladislai de Rakounk."

${ }^{83}$ CD, X (1912.), 423 (20.11.1338.) i XI (1913.), 115 (18.2.1344.). - „...Thomas filius Dominici de Rakounig.“ (1338.) i „...Thoma filii Dominici, in possessione Rakonuk vocata existentem.“ (1344.)

${ }^{84}$ Stipišić, Jakov i Šamšalović, Miljen (1960.), str. 621. - "Petrus Bykzaad ... possessionis suae Wyhel...” 
drugoj polovici 15. stoljeća, to je gotovo sigurno, budući da je na sjeveroistočnom zidu svetišta crkve u njegovo doba naslikana svečeva slika.

Izbor titulara crkve u Novom Mjestu, sveto usmjerenje njezina broda, ali i imena dominikanskih svetaca među nasljednicima Ladislava Rakovečkog, upućuju na zaključak da su dominikanci izravno ili posredno sudjelovali u njezinoj gradnji. Nije poznato je li neki od članova obitelji bio redovnik toga propovjedničkoga reda, no, sudeći prema dvojici sinova Jurja Bisaškoga koji su bili svećenici, jedan je bio župnik (Martinus presbyter) a drugi kapelan (capellanus Petri), ${ }^{85}$ takva mogućnost nije isključena.

\section{Crkva sv. Petra mučenika - privatna crkva obitelji Rakovečki}

Sudeći prema arhitekturi i sačuvanim fragmentima zidnih slika na trijumfalnom luku i na sjeverozapadnom zidu broda, crkva sv. Petra mučenika bila je dovršena prije prvog poznatog popisa župa zagrebačke biskupije godine $1334 .{ }^{86}$ Razlog njezina nespominjanja u tom popisu unatoč izgrađene crkve, vjerojatno je $\mathrm{u}$ tome što do te godine u Novom Mjestu još nije bila utemeljena župa.

U doba ugarsko-hrvatskoga kralja Stjepana II. (1116.-1131.) u gradnji crkve trebalo je sudjelovati deset sela, ${ }^{87} \mathrm{kralj}$ je za crkvu trebao dati svećeničko ruho i tkanine za oltar, a biskup svećenike i knjige. ${ }^{88} \mathrm{U}$ usporedbi s tim zakonikom Stjepana II. ${ }^{89}$ Ladislav Rakovečki crkvu sv. Petra mučenika dao je sagraditi na mjestu na kojemu nije bilo naselja i na kojemu se ono tek trebalo razviti (Novo loco). Zabilježba u kanonskoj vizitaciji iz godine 1704. da je kapela sagrađena na mjestu na kojem je nekoć bila utvrda nije potvrđena arheološkim istraživanjima. ${ }^{90}$

Crkva je u trećem desetljeću 14. stoljeću još bila privatna (Eigenkirche $\left.{ }^{91}\right)$ ili dvorska crkva ${ }^{92}$ obitelji Rakovečki, no za razliku od utvrđenih posjeda Rakovec

\footnotetext{
${ }^{85}$ Stipišić, Jakov i Šamšalović, Miljen (1960.), str. 586. (2344 D-XIII-7). - „Martinus presbyter, capellanus Petri, filii qd. Georgii de Bykzaad..."

${ }^{86}$ Buturac, Josip (1984.), str. 90.

${ }^{87}$ Sela su crkvi trebala izgraditi župni dvor i dati dva kmeta, konja i kobilu, šest volova, dvije krave i 30 manjih životinja. Pál, Engel, The Realm of St Stephen. London-New York, 2001., str. 46.

${ }^{88}$ Pál, Engel, (2001.), str. 46.

${ }^{89}$ Pál, Engel (2001.), str. 46. (bilj. 22.) i 388 (bilj. 22): Stjepan II: 1 (LMH, vol. 1 p. 9)

${ }^{90}$ NAZ, Kanonske vizitacije. Protokol br. 130/I., str. 186. - "Haec capella videlicet esse aedificata in loco in quo olim castellum erat".

${ }^{91}$ Pál, Engel, (2001.), str. 44.

${ }^{92}$ Stošić, Josip, "Srednjovjekovna umjetnička svjedočanstva o zagrebačkoj biskupiji”. Katalog izložbe: Svetitrag, devetsto godina umjetnosti zagrebačke biskupije 1094 - 1994. Zagreb, 1994., str. 121.
} 
(castrum) $)^{93}$ i Bisag (Bikzad cum Castello ibi habito), ${ }^{94}$ Novo Mjesto nije imalo kaštel, a njezin osnivač Ladislav Rakovečki vlastelinstvom je upravljao iz Rakovca. O tome da je bila dvorska crkva trebalo bi svjedočiti postojanje empore uz jugozapadni zid broda s koje je velikaš pratio službu Božju..$^{95}$

Od izgradnje i opremanja crkve do popisa župa u zagrebačkoj biskupiji 1334., čini se da je Novo Mjesto bilo slabo naseljeno, nedovoljno da bi se oko nove crkve formirala župa. O tome na koji su način vlastela nastojala privući ljude na svoja imanja svjedoči isprava kojom je ban Mikac pozivao i nudio pogodnosti ljudima koji bi naselili nedaleko trgovište Zelinu u Moravču. ${ }^{96} \mathrm{Je}$ li i kakve je pogodnosti mogao nuditi Ladislav Rakovečki za naseljavanje Novog Mjesta nije poznato. U drugoj polovici 16. stoljeća iz sličnih razloga, premalog broja stanovnika, župa u Novom Mjestu se ugasila. Za godinu 1574. povijest zagrebačkih sinoda navodi da je župa bez župnika: Ad novo mezto vacat. ${ }^{77}$ Od prvog spominjanja u kanonskim vizitacijama godine 1704. do danas crkva u Novom Mjestu navodi se isključivo kao kapela. ${ }^{98}$

\section{POKROVITELJI OSLIKAVANJA CRKVE TIJEKOM 14. STOLJEĆA}

\section{Ladislav Rakovečki}

Utemeljenje crkve u Novom Mjestu godine 1302. može se pripisati Ladislavu Rakovečkom (Ladislai de Rakounk), tadašnjem vlasniku rakovečkoga vlastelinstva i njegovim potomcima. ${ }^{99}$ Isprva su zidovi bili obojeni svijetlo sivkasto-modrom bojom. Sačuvani nevješto nacrtani crveni kvadri u luneti na sjeveroistočnom zidu svetišta svjedoče o njihovom prvotno skromnom ukrašavanju. Modrikasti tragovi boje uočeni su i na jugoistočnom i jugozapadnom zidu broda.

Oslikavanje crkve freskama započelo je na zidovima trijumfalnog luka i broda. Među onima iz najstarijeg slikanog sloja na trijumfalnom luku valja istaknuti scenu Majka milosrda i fragmente donatora, a na sjeverozapadnom zidu broda više fragmenata ciklusa Legende o sv. Ladislavu (crteži II. i III.)

\footnotetext{
${ }^{93}$ Franjo, Pajur (2016.), str. 87. i dalje.

${ }^{94}$ Arhiv HAZU, I d 12, e!en. IV, p. 25.

${ }^{95}$ Stošić, Josip, (1994.), str. 121.

${ }^{96}$ CD IX (1911.), str. 418-419. (346.) - Zelinska kronika (1994.), str. 27-28. (48.)

97 Tkalčić, Ivan Krstitelj, "Prilog za povijest zagrebačkih sinoda u XV. I XVI. vieku." Starine JAZU, knjiga XVI, Zagreb, 1884., str. 127.

${ }^{98}$ Srša, Ivan, (1998.), str. 74-76.

${ }^{99}$ Ladislav je umro prije godine 1326. u kojoj se njegova supruga spominje kao udovica (viduae Ladislai). Stipišić, Jakov i Šamšalović, Miljen (1959.), str. 301. - Regestum documenti suspecti.
} 


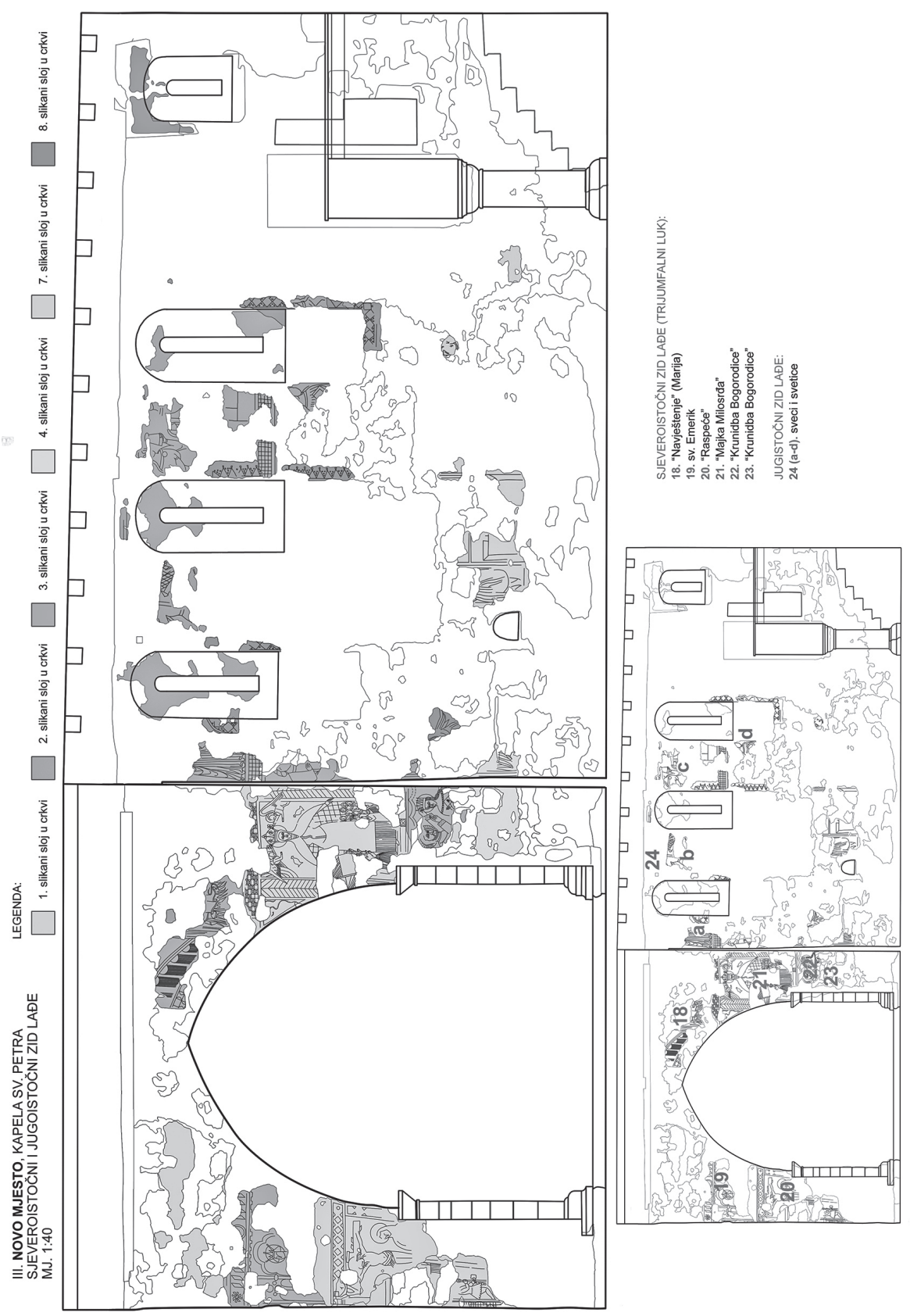

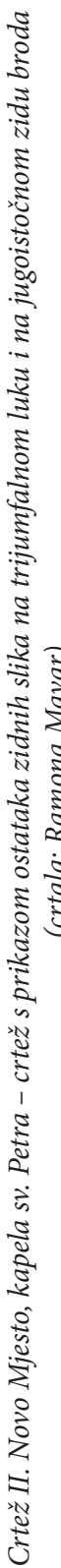




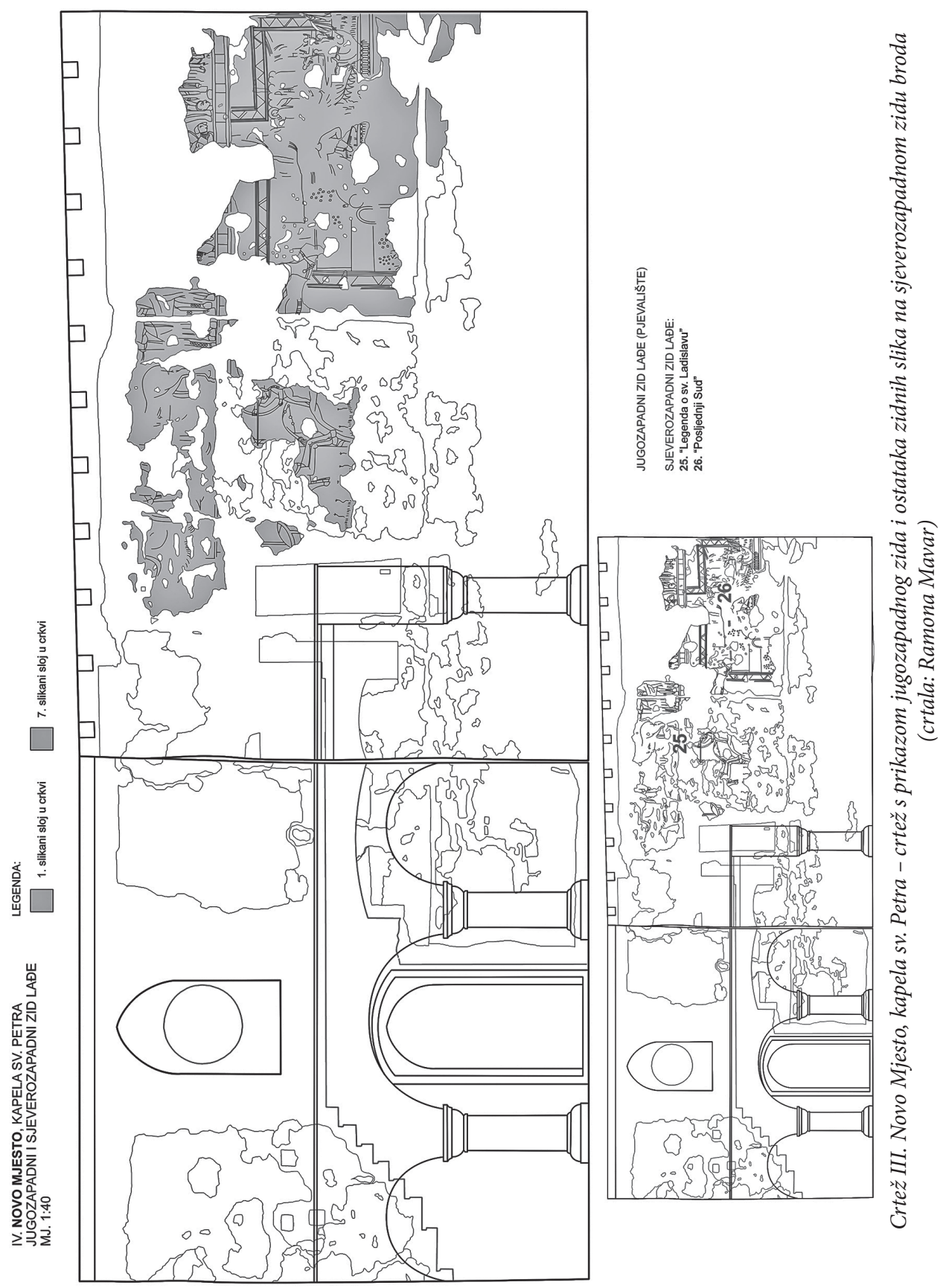


Počevši od posljednje četvrtine 13. stoljeća prikazivanje Majke milosrđa na zidu trijumfalnog luka postalo je uobičajeno, katkad je slikana južno, a katkad sjeverno od njegova otvora. Prema srednjovjekovnom pravilu muškarci i žene u crkvi su sjedili odvojeno, muškarci na južnoj, a žene na sjevernoj strani. ${ }^{100}$ Majka milosrđa u nekim je crkvama i kapelama slikana sjeverno, a u drugima južno od otvora trijumfalnog luka. ${ }^{101}$ Razlozi odstupanja od pravila nisu uvijek jasni. U Novom Mjestu pretpostavljeni razlog prikazivanja scene Majke milosrđa na "muškoj strani", južno od otvora trijumfalnog luka (sl. 1), možda je istodobni ciklus zidnih slika na čitavoj površini sjeverozapadnog zida u brodu posvećen Legendi o sv. Ladislavu.

Sl. 1. Novo Mjesto, kapela sv. Petra, trijumfalni luk - Majka milosrda (foto: Ivan Srša)

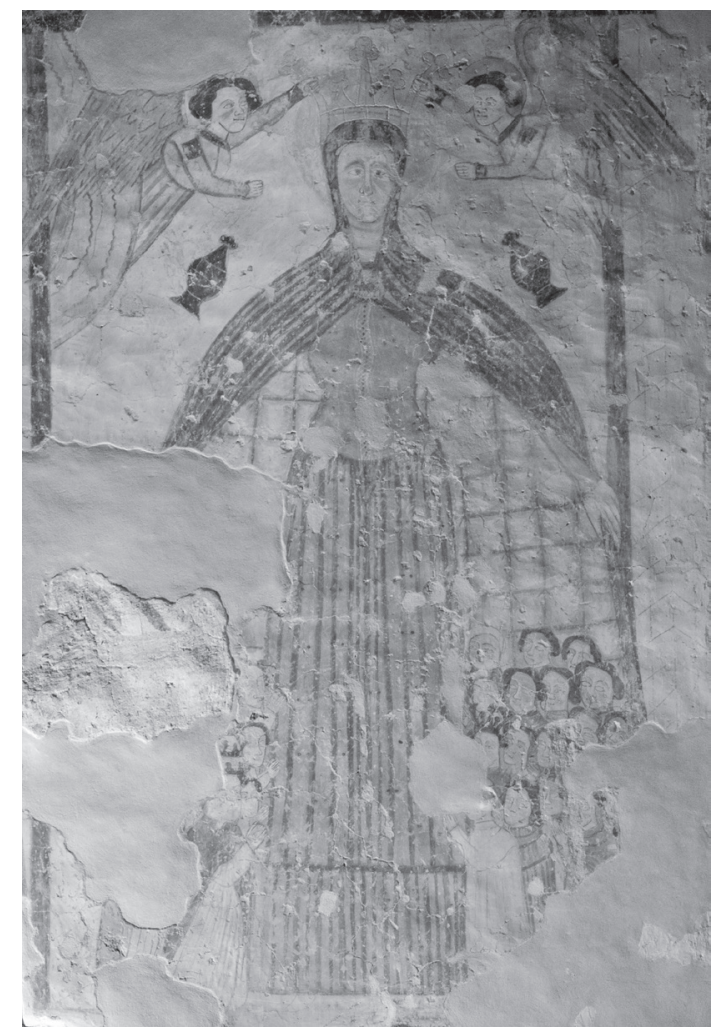
25.

${ }^{100}$ Durandus, Guilielmus, (2007.), The Rationale Divinorum Officiorum. Louisville, 2007., str.

${ }^{101}$ Prizori Majke milosrđa na “ženskoj strani”, sjeverno od otvora trijumfalnog luka sačuvani su primjerice u Požegi (crkva sv. Lovre), Ivaniću Miljanskom (kapela sv. Ivana Krstitelja) i na sjevernom zidu svetišta u Belcu (crkva sv. Jurja). Na "muškoj strani” pored crkve u Novom Mjestu ta je scena fragmentarno očuvana i u Zajezdi (crkva Uznesenja Marijina). 
Da je taj ciklus slikan na njegovom jugoistočnom zidu scene bi isprekidale prozorske niše, a izravna svjetlost s prozora ometala bi promatrača.

Ladislav Rakovečki spomenuti je ciklus dao naslikati u spomen na svoga sveca-zaštitnika. U legendi se uobičajeno navode svečeve borbe s Kumanima i Pečenezima, koje se katkad naziva poganima. ${ }^{102}$ U Novom Mjestu kronološki su prikazane Ladislavove borbe s oba naroda: $\mathrm{u}$ četvrtom (najgornjem) registru neposredno pod stropom prikazana je Ladislavova borba s Pečenezima, a u trećemu s Kumanima (sl. 2.). S Pečenezima se Ladislav zajedno s bratom Gezom i kraljem Salomonom borio godine 1068. u bitki kod Kerlésa (Chiraleş), ${ }^{103}$ a s

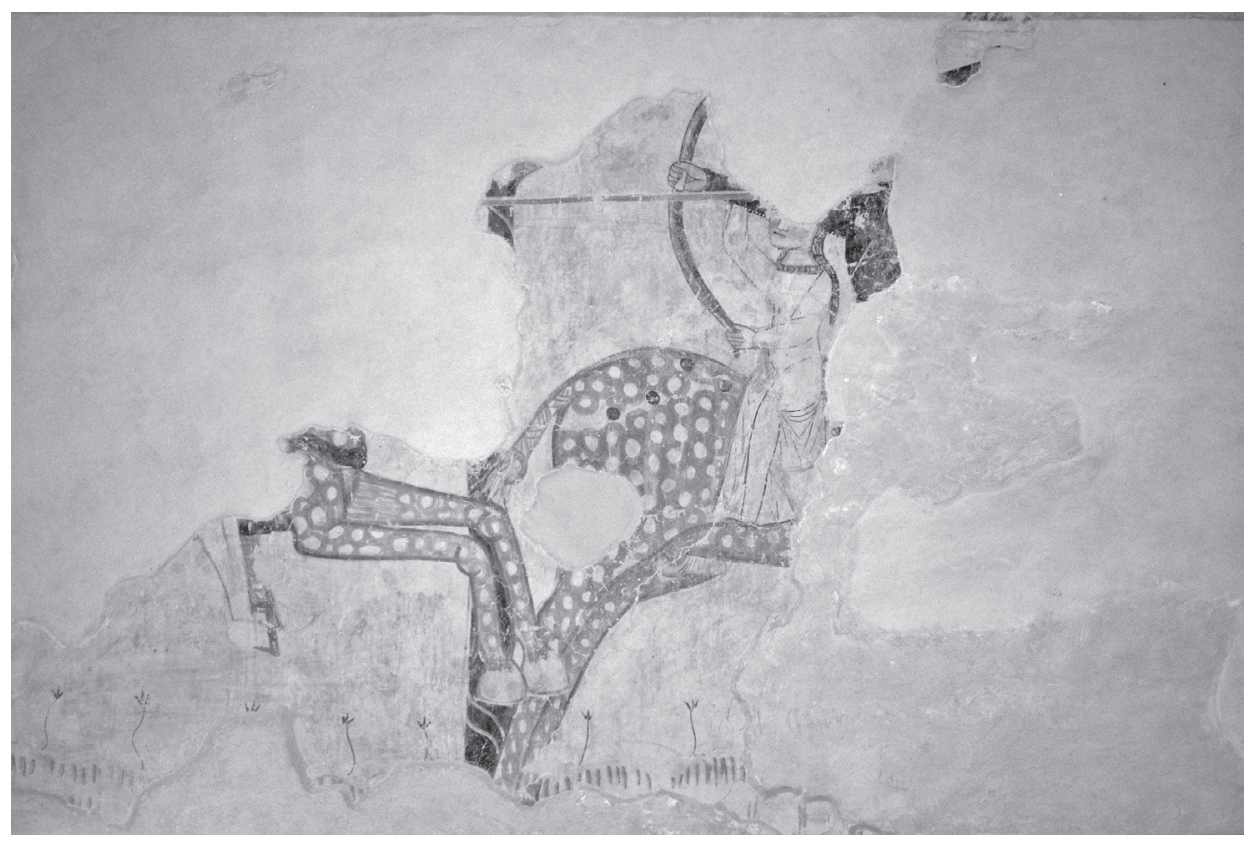

Sl. 2. Novo Mjesto, kapela sv. Petra, sjeverozapadni zid broda - detalj Legende o svetom Ladislavu (foto: Ivan Srša)

${ }^{102}$ St. Ladislaus legend, http://historum.com/european-history/63862-images-legend-saint-ladislaus-14th-15th- centuries-print.html (pristupljeno 21.3.2017.) - "The sequence of the events portrayed is generally similar all over the churches in medieval Hungary: 1. Saint Ladislaus riding his horse in the battlefield catches sight of a pagan warrior holding a Hungarian girl in his saddle. 2. Saint Ladislaus begins to pursue him. 3. Saint Ladislaus could not catch up to him 4. Saint Ladislaus shouts to the girl: "Catch hold of the pagan at his belt and jump to the ground!" 5. The girl does so, and the two warriors, the king and the pagan, begin wrestling. 6. Saint Ladislaus cannot subdue him, therefore the girl helps the king. She cuts the pagan's Achilles tendon. 7. Saint Ladislaus beheads the pagan with the help of the girl. 8. In the last scene Saint Ladislaus is resting in the arms of the girl." 
Kumanima godine 1091. ${ }^{104} \mathrm{U}$ drugom registru sačuvan je tek manji fragment na osnovi kojega nije moguće odrediti o čemu se radi. ${ }^{105}$

Dijelovi legende nastali su još u vrijeme Ladislavova nasljednika, kralja Kolomana (Gesta Ladislai regis) i od tada se ona postupno dorađivala. Službena verzija legende o $s v$. Ladislavu kompilacija je nastala početkom 13. stoljeća. ${ }^{106}$ Napose je zanimljiva razlika između dva kodeksa ilustrirane ugarske povijesti: stariji je nastao za kralja Roberta I. Anžuvinca oko 1330. ${ }^{107}$, a mlađi - započet poslije 1358. i dovršen između 1370. i 1373. - za njegova sina Ludovika I. ${ }^{108}$

U starijem kodeksu djevojka u sceni Borbe Ladislava s Kumanom pomaže kralju i ozljeđujući pogana sjekirom. U mlađoj ilustriranoj kronici djevojka moli Ladislava da pogana poštedi i pusti! Blaženi Ladislav (btissimus Ladislaus) vidjevši jednog pogana da je oteo ugarsku djevojku i misleći da je riječ o kćerki varadskog biskupa (filiā epī varadiensis) dao se u potjeru. No, kad ga je nakon borbe kanio ubiti, djevojka ga moli da pogana poštedi i pusti. "Bilo je vidljivo da u njoj nema vjere; vjerojatno je željela da ga se pusti zbog njezine snažne tjelesne ljubavi." Međutim, nakon dugotrajne borbe svetac (scs autem dux) je pogana ipak ubio. Završnim opisom u mlađoj kronici se konstatira da djevojka ipak nije bila biskupova kći (illa filia epī non fuit). Razlog drastične promjene starije varijante legende nije poznat. ${ }^{109}$

${ }^{103}$ Kronika spominje bitku s Kunima, no suvremena historiografija navodi da su to bili Pečenezi. Chronicon pictum (Chronica de Gestis Hungarorum), Képes Krónika, str. 72. - Legenda o sv. Ladislavu https://web.archive.org/web/20120304111134/http://konyv-e.hu/pdf/Chronica_Picta. pdf (Pristupljeno 12.12.2017.)

${ }^{104}$ Pal, Engel, (2001.), str. 32. i 37.

${ }^{105} \mathrm{U}$ tom registru kronološkim redom mogle su biti neke od scena koje su prikazane u Turnišću (Slovenija): Povratak pobjednika, Ladislavova krunidba, Mladi svetac nudi svoju krunu svetom redovniku i Gradnja katedrale u Varadu. - Prokopp, Maria (1983.), Italian trecento inlfuence on murals in east central Europe particularly Hungary. Budapest, 1983., str. 142.

${ }^{106}$ Klaniczay, Gábor, Holy Rulers and Blessed Princes: Dynastic Cults in Medieval Central Europe. Cambridge, 2011.

${ }^{107}$ Anjou Hungarian Legendarium, Biblioteca Apostolica Vaticana.

${ }^{108}$ Chronicon pictum (Chronica de Gestis Hungarorum), Képes Krónika, str. 72.

${ }^{109}$ Je li legenda izmijenjena ubacivanjem djevojčine snažne tjelesne ljubavi, ne bi li se prikrila prvotna verzija koja se mogla tumačiti kao kraljeva nemoć jer je pogana svladao tek uz djevojčinu pomoć? 


\section{Nasljednici Ladislava Rakovečkog ${ }^{110}$}

Nakon smrti Ladislava Rakovečkog u drugoj četvrtini 14. stoljeća njegovi su nasljednici nastavili s oslikavanjem trijumfalnog luka i oba bočna zida broda. Među više fragmenata drugog slikanog sloja najistaknutiji je prizor Krunidbe Bogorodice južno od otvora trijumfalnog luka (sl. 3.) i vrlo fragmentarno očuvani likovi svetica i apostola na jugoistočnom zidu broda.

Scena Krunidbe Bogorodice naslikana je neposredno ispod scene Majke milosrđa, poviše koje su fragmentarno očuvani detalji haljine Bogorodice iz gotovo posve uništene scene Navještenja. Između prozora u četvrtom registru na jugoistočnom zidu broda, po svojim se atributima prepoznaju sv. Barbara s kulom u ruci i $s v$. Katarina s kotačem. U registru ispod prozora fragmentarno sačuvani likovi trojice svetaca s knjigom u rukama upućuju na niz apostola. Na tom zidu je najmanje sačuvanih fragmenata zidnih slika, najvećim dijelom one su stradale prilikom povećavanja prozora potkraj 19. ili početkom 20. stojeća.

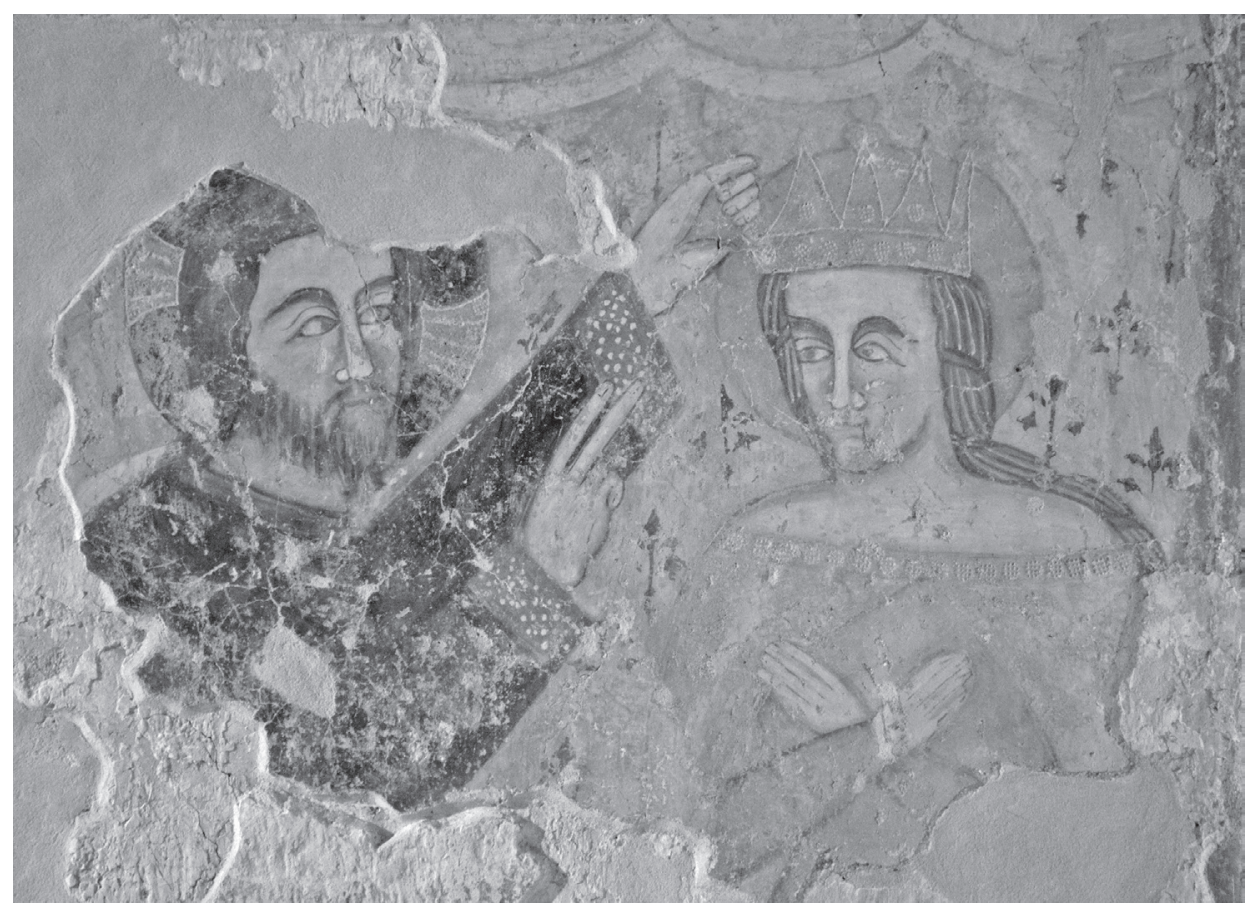

Sl. 3. Novo Mjesto, kapela sv. Petra, trijumfalni luk - Krunidba Bogorodice (foto: Ivan Srša)

${ }^{110}$ DZ, IX (1911.) str. 571-572 (6.10.1331.) - “... Martinus et Nicolaus filii Ladislai, Nicolaus, Dominicus, Stephanus et Jacobus filii Abre filii eiusdem Ladislai fideles nostri de Rakonuk...” 


\section{Emerik Bisaški (Emericus filius Mykech de Bykzad ${ }^{111}$ )}

Fragmentarno sačuvan prizor s likom svetog kralja ispod kojega kleči donator, sjeverno od otvora trijumfalnog luka, pripada trećem sloju zidnih slika, nastalom u drugoj polovici 14. stoljeća. Golobradi mladić najvjerojatnije je ugarski kralj sveti Emerik (1007. - 1031.), najmlađi među trima svetim ugarskim kraljevima (sl. 4.). Svetac je naslikan ispod trolisno oblikovanog luka koji počiva na kapitelima s izvrnutim krnjim piramidama i istaknutim torusom. S obje svečeve strane izvorno je bila naslikana po jedna bifora, od kojih je djelomice sačuvana sjeverna. U usporedbi s oba prethodna slikana sloja mladoliki sveti Emerik znatno odudara, čitava scena naknado je umetnuta i nema pandan među očuvanim ostalim fragmentima zidnih slika, ni u brodu ni u svetištu.

Slikanje svetog kralja može se povezati s vlasnikom susjednog (bisaškog) vlastelinstva, trećeg ogranka Rakovečkih, magistrom Emerikom koji se dvaput spominje u godini 1389: 12. ožujka (Emericus filius Mykech de Bykzad) i 1. travnja (Emericus filius Mykech de dicta Bykzad). ${ }^{112}$

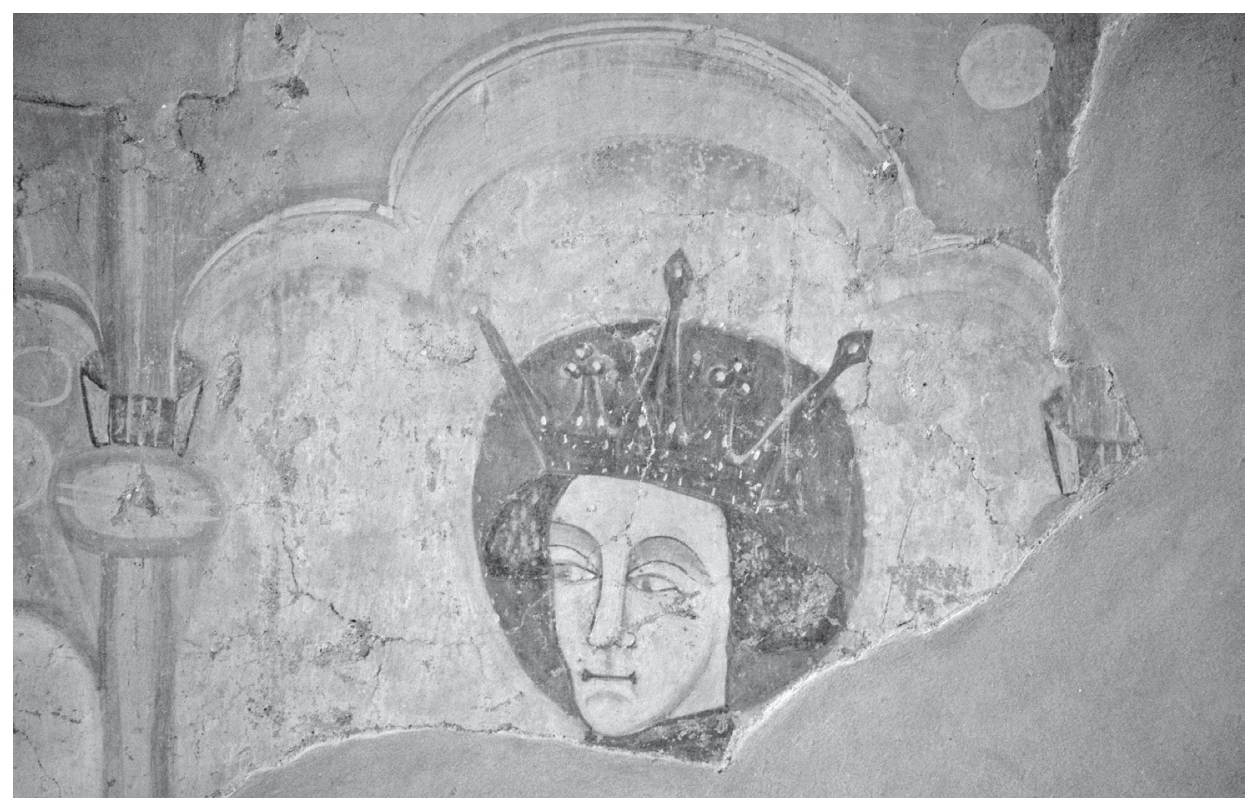

Sl. 4. Novo Mjesto, kapela sv. Petra, trijumfalni luk - Sveti Emerik (foto: Ivan Srša)

${ }^{111}$ CD, XVII (1981.), Zagreb, str. 188.

${ }^{112}$ CD, XVII (1981.), str. 188. i 192. 


\section{POKROVITELJI OSLIKAVANJA CRKVE U 15. STOLJEĆU}

Fridrik II i Ulrik II Celjski (Fridricus et eiusque fiiius Ulricus, Ciliae comites)

Godine 1438. Juraj, sin Franje (Georgius, filius Francisci de Zenth-Peter), spori se pred čazmanskim kaptolom zbog posjeda Sveti Petar i susjednih sela koje su zaposjeli grofovi Fridrik i Ulrik Celjski. ${ }^{113}$ Celjski su posjedovali navedeno vlastelinstvo do Ulrikove smrti 1456. Na čelu zagrebačke biskupije tih je godina bio Benedikta I. de Zolio (1440.-1453.): "Među najodličnije građane koji dolaze na Gradec u doba Celjskih valja bez sumnje ubrojiti zagrebačkoga biskupa Benedikta ...,", kojega su na čelo zagrebačke biskupije progurali Celjski. ${ }^{115}$

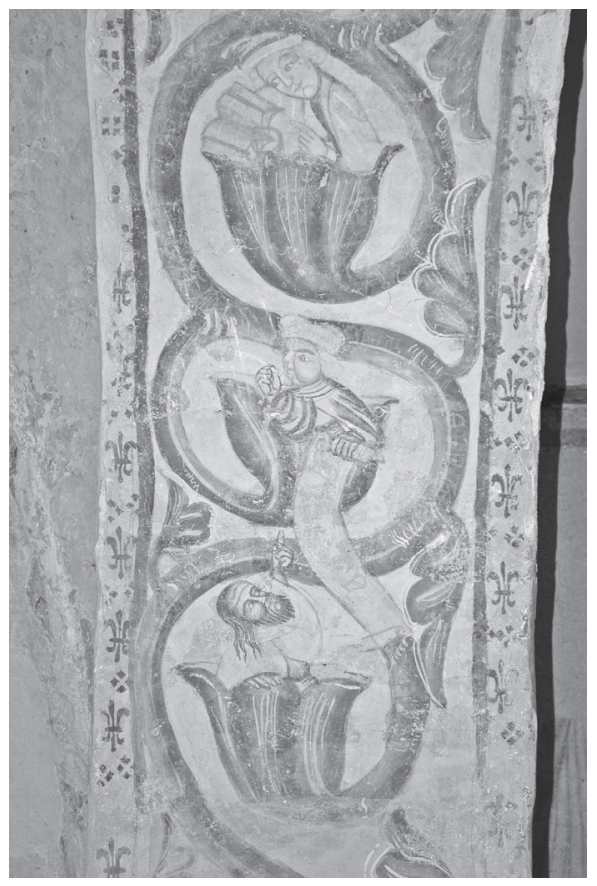

U doba grofova Celjskih oslikani su lučni dio trijumfalnog luka s temom Jeseova stabla (sl. 5. $i$ crtež $I V.)^{116}$ i svetište. U četiri svodna jedra širokom ukrasnom trakom podijeljena na dva polja bilo je naslikano osam anđela, po dva u svakom jedru. Slaba i fragmentarna očuvanost naslikanih anđela onemogućuje pouzdano određivanje kojoj su od triju anđeoskih sfera pripadali. Jedini među očuvanim likovima anđela koji u ruci drži otvorenu knjigu naslikan je u južnom polju jugozapadnog jedra.

Sl. 5. Novo Mjesto, kapela sv. Petra, lučni dio trijumfalnog luka - Jeseovo stablo (foto: Ivan Srša)

${ }^{113}$ Stipišić, Jakov i Šamšalović, Miljen (1960.), str. 564. -“Georgius, filius Francisci de ZenthPeter, Fridricum eiusque fiiium Ulricum et nepotem Hermannum, Ciliae comites, ab occupatione possessionis suae Zentli-Peter et vicinarum villarum coram capitulo Chasmensi iuridice probibet."

${ }^{114}$ Klaić, Nada (1982.), Zagreb u srednjem vijeku. Zagreb, 1982., 219.

${ }^{115}$ Buturac, Josip (1944.), str. 39.-40.

116 Tekst o Jeseovu stablu objavljen je u Zborniku radova sa znanstvenog skupa održanog 15. prosinca 2000. godine u Sv. Ivanu Zelini. HAZU, Razred za društvene znanosti, Odsjek za povijesne znanosti Zavoda za povijesne znanosti i Grad Sveti Ivan Zelina. Zagreb, 2003. - Srša, Ivan (2003.), "Jeseovo stablo" u kapeli sv. Petra u Novom Mjestu. str. 295. - 305. 

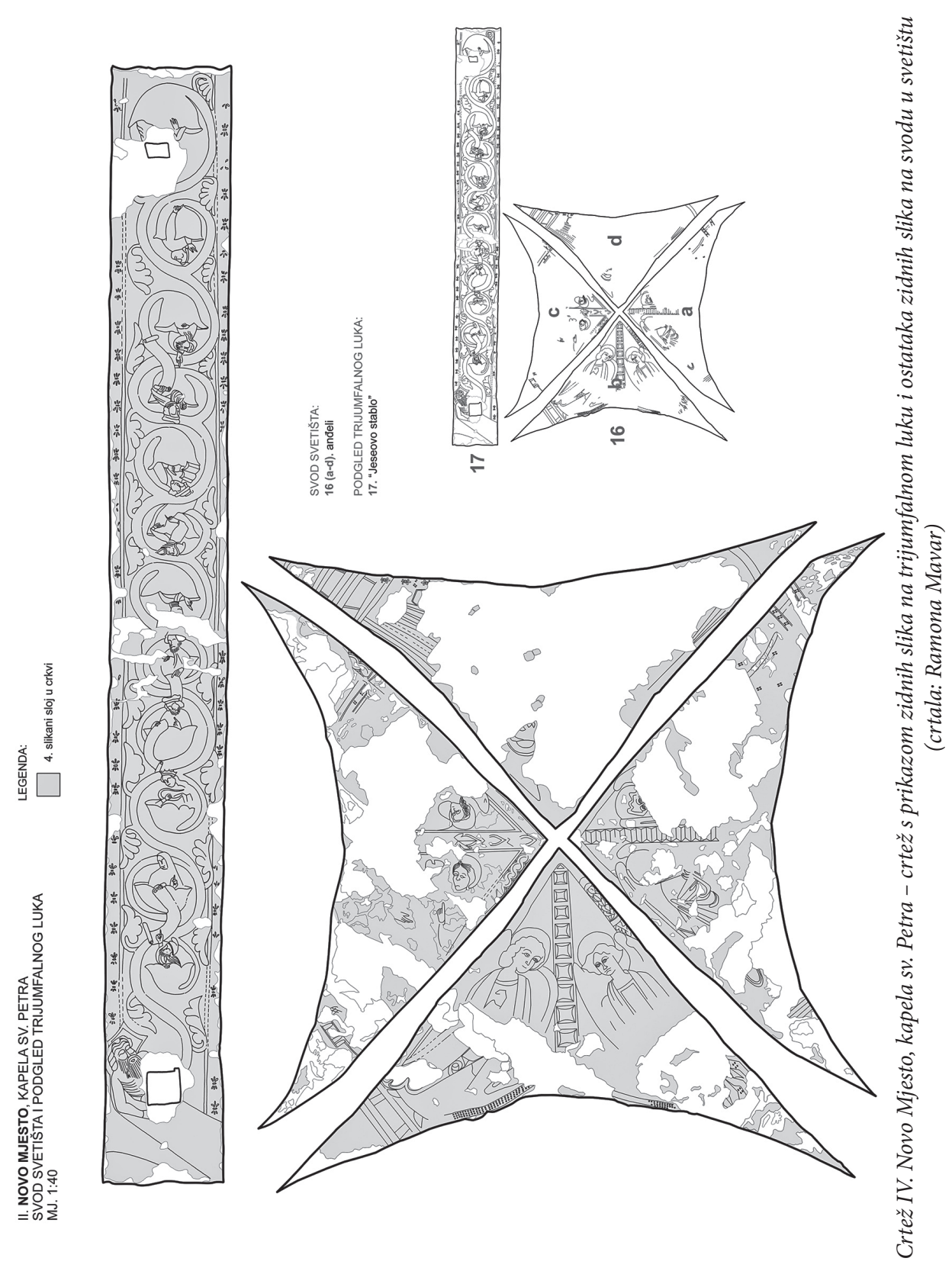
Knjiga kao atribut pripisuje se anđelima vrlina (Virtutes), ${ }^{117}$ ali i andelima gospodstva (Dominationes). ${ }^{118}$ Broj od čak osam anđela na oslikanom svodu u Novom Mjestu možda prije upućuje na anđele gospodstva. ${ }^{119}$ Njihov bi se broj moglo povezati s brojem dana od Kristova ulaska u Jeruzalem do njegova Uskrsnuća. ${ }^{120}$

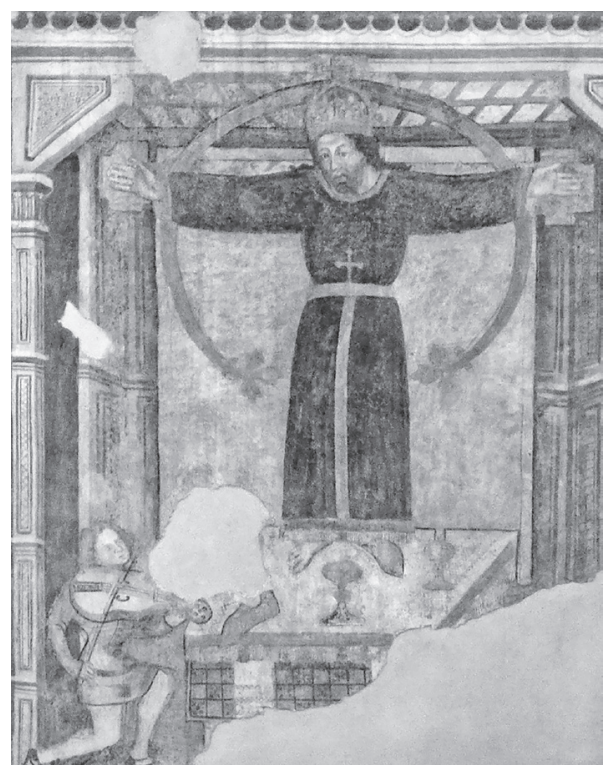

Sl. 6. Bolzano, La chiesa dei Domenicani - Volto Santo di Lucca. [Bolzano, Chiesa dei domenicani. http://www.bolzano.net/it/chiesa-domenicani.html (pristupljeno 26.12.2017.)]

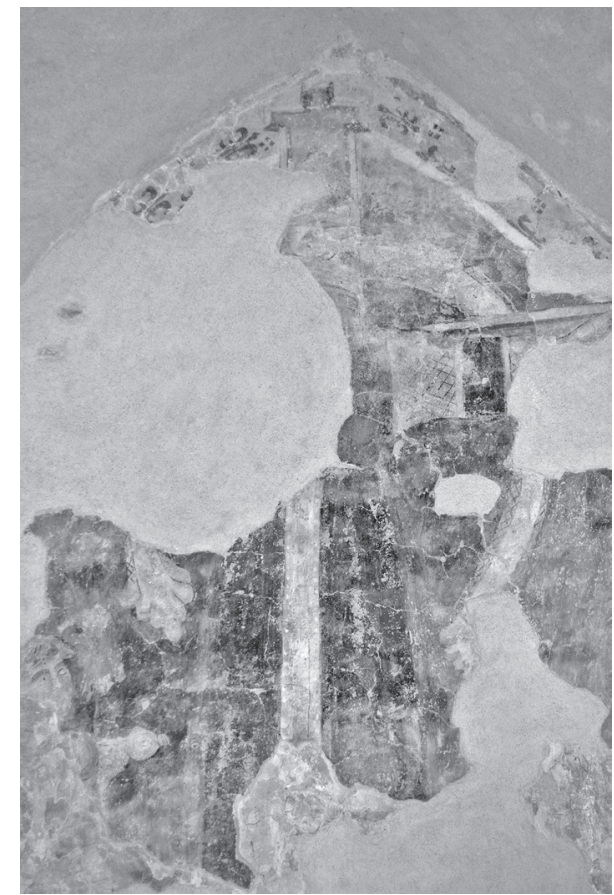

Sl. 7. Novo Mjesto, kapela sv. Petra, sjeverozapadna luneta u svetištu - Sveto lice iz Luccae (foto: Ivan Srša)

${ }^{117}$ Fučić, Branko, "Anđeli”, u: Leksikon ikonografije, liturgike i simbolike zapadnog kršćanstva. Zagreb, 1979, str. 115.

${ }^{118}$ Murphy, Mary Agnes, The representation of angels and angelic orders from the late middle ages through reformation c. 1450 - c. 1650. Leicester, 2010., str. 160-175.http://www.e-bookdownload.net/ downloadbook.php?book=kq3QxWIbbdAC (28.11.2017.)

119 "East Window of the Beauchamp Chapel, Collegiate Church of St Mary, Warwick, c. 1443 1447." u: Murphy, Mary Agnes (2010.).

${ }_{120}$ Bible Study site. http://www.biblestudy.org/bibleref/meaning-of-numbers-in-bible/8.html (28. 11. 2017.) 

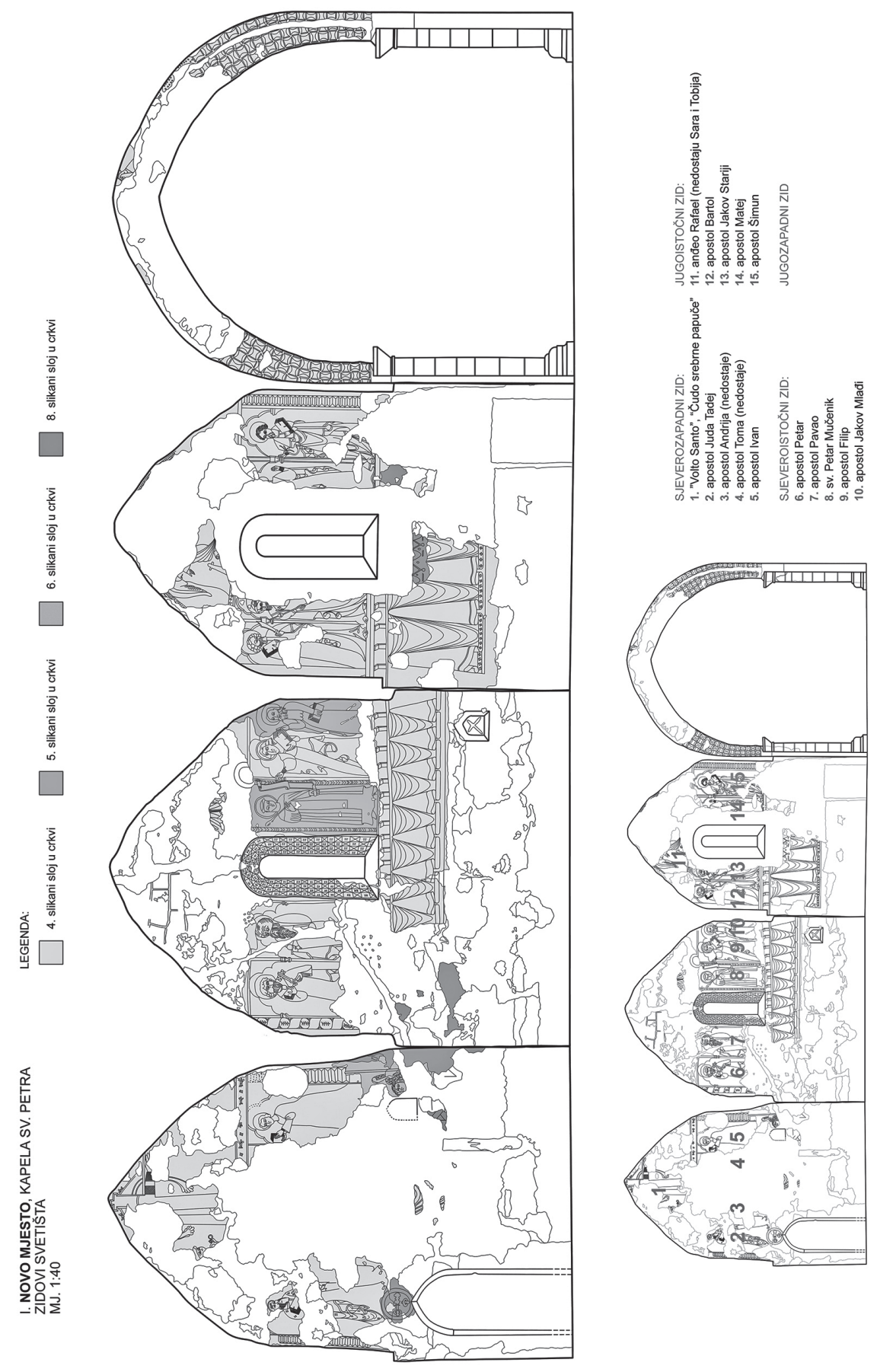

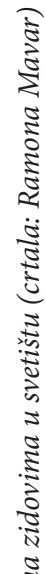
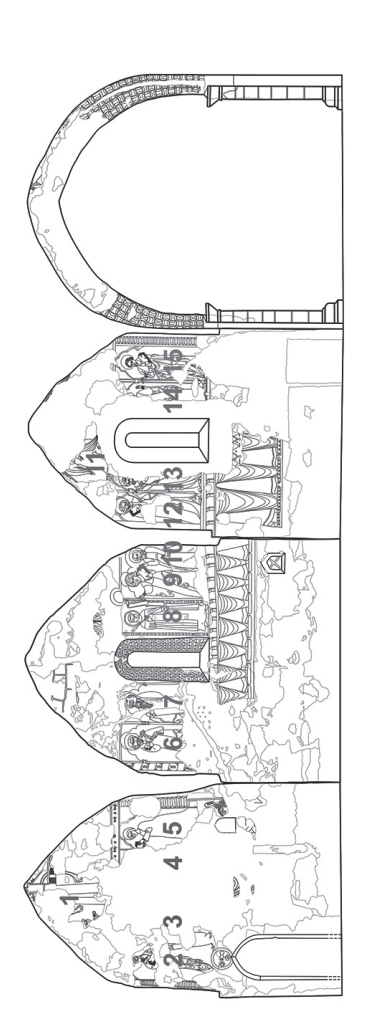

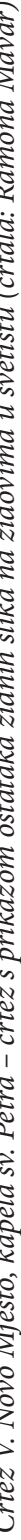


U luneti na sjeverozapadnom zidu svetišta sačuvani su fragmenti zidne slike sa scenom "Sveto lice iz Luccae" (Volto Santo di Lucca): Krist na križu s tijarom na glavi, odjeven u tuniku do gležnja (colobium), a u podnožju s desne strane križa sačuvana je glava mladića koji gleda u Krista (sl. 6. i 7., crtež V.). Podrijetlo toga prizora potječe od kopije drvene skulpture datirane u početak 13. stoljeća, a potkraj 15. stoljeća (1484.) smještene u oktogonalnu mramornu kapelu (tempietto) u katedrali San Martino (Lucca). Sačuvani fragmenti u Novom Mjestu svjedoče da je riječ o Čudu srebrene papuče, jednoj od legendi "Svetog lica iz Luccae". ${ }^{121}$

"Sveto lice iz Luccae" bilo je predmet pobožnosti plemstva i oba propovjednička reda. Ta je pobožnost uvrštena u francusko izdanje Zlatne legende (1410.1450.) s minijaturama među kojima je i scena sa sviračem kojoj nalikuje freska u Novom Mjestu. ${ }^{122} \mathrm{U}$ zidnom slikarstvu ta se scena slikala diljem Europe, napose tijekom posljednje četvrtine 14. stoljeća (Assisi, basilica de Santa Chiara; Bolzano, San Domenico, sl. 6; Parma, baptisterij; Bregenz, Martinskapelle, itd.) i tijekom 15. stoljeća (Verona, Casa di Giulietta; San Viglio, Castelvecchio; Garmisch Partenkirchen, San Martino; Düsseldorf, Sankt Lambert; Prevole, cerkev sv. Križa).

Putovanja grofa Friedricha II. Celjskog u Rim uglavnom su poznata, ${ }^{123}$ manje je poznato putovanje njegova sina Ulrika II. u Santiago de Campostela godine 1430. ${ }^{124}$ "Ulrika je na hodočašću primio kastiljski kralj Juan II. od kojega je primio viteštvo." ${ }^{25}$ Juan II. (1405. - 1454.) na svom je dvoru Ulrika II. Celjskog odlikovao ordenom Devisa del collar del escama, kojim je odlikovao i nekolicinu drugih srednjoeuropskih vitezova. ${ }^{126}$ Šest godina poslije Fridrik II. i Ulrik

${ }^{121}$ Calabrese, Chiara (2016.), "The Volto Santo, the Minstrel and the Cleaver." Tuscany's Grapevine Magazine, 2016.

${ }_{122}$ ARVO, archivo digitale del Volto Santo. http://www.archiviovoltosanto.org/en/node/45 (23.3.2017.)

${ }^{123}$ Srša, Ivan, "Imaju li zidne slike u crkvi sv. Ivana u Ivaniću Miljanskom i skriveno značenje?" Kaj, br. 1-2, 2009, 61-91.

${ }^{124}$ Grabmayer, Johannes, Domenig, Christian (2005.), Die Grafen von Cilli und ihr Archiv. „Histoire des Alpes = Storia Delle Alpi = Geschichte der Alpen“, 10/2005., str. 79. - „So stattet Friedrich II. seinen Sohn Ulrich anlässlich dessen Ritterfahrt nach Santiago de Compostela, die dieser gemeinsam mit 60 Rittern unternimmt, mit der riesigen Summe von 32`000 Gulden aus, um Ulrich eine standesgemäße Reisehofhaltung zu ermöglichen (Ulrichs Tante leiht ihm dafür weitere 5000 Gulden).“

${ }^{125}$ Kurelić, Robert, Pregled povijesti grofova Celjskih. https://www.academia.edu/3645279/ Pregled povijesti grofova Celjskih Overview of the History of the Counts of Cilli (28.3.2017.)

${ }^{126}$ Álvaro Fernández de Córdova Miralles, Las divisas del rey. Escamas y ristres en la Corte de Juan II de Castilla (el collar de la Escama y la divisa del ristre), RS, str. 36. https://www.academia. edu/6113850/Las divisas del rey. Escamas y ristres en la Corte de Juan II de Cast illa el collar_de_la_Escama_y_la_divisa_del_ristre (pristupljeno 29.3.2017.) 
II. uzdignuti su na čast knezova Svetoga rimskog carstva (1436.). "Oni nisu više comites, nego principes. Ulrik se postepeno uzdiže do suvladarskog položaja, on je neokrunjeni kralj." ${ }^{127}$

Nije isključeno da su dvije godine poslije (1432.) obojica ili jedan od njih bili i u malobrojnoj pratnji kralja Žigmunda na putu u Rim. Žigmund je najprije išao u Piacenzu, a potom u Luccau, u kojoj se zadržao između 31. svibnja i 11. srpnja, nakon čega je otputovao u Siennu. ${ }^{128}$ Ako su grofovi Celjski zajedno s kraljem ili zasebno boravili u Luccai imali su priliku pokloniti se "Svetom licu" i iz prve ruke upoznati s popularnom pričom o francuskom hodočasniku i srebrnoj papuči, koju su potom dali naslikati u sjeverozapadnoj luneti crkve u Novom Mjestu.

$\mathrm{Na}$ fragmentu oslikane žbuke $\mathrm{u}$ istočnoj polovici jugoistočne lunete sačuvan je donji dio stojećeg lika anđela velikih krila, desnog spuštenog uz tijelo i lijevog zakrivljenog udesno (crtež $\boldsymbol{V}$.). Velika praznina iza Rafaela okrenutog istoku daje naslutiti da se iza arkanđela odvijao ostatak danas izgubljene scene, s likovima arkanđela Rafaela, Tobije i psa na putu do Sare, buduće Tobijine supruge. ${ }^{129}$

Na trima svetišnim zidovima ispod luneta bili su prikazani apostoli, a najbolje su očuvani na čelnom (sjeveroistočnom) zidu (crtež $V$.). U sjevernom dijelu sjeveroistočnog zida po svojim su atributima prepoznatljivi likovi sv. Petra $i s v$. Pavla, a u istočnom dijelu jugoistočnog zida sv. Bartol i sv. Jakov Stariji. Svi ostali sačuvani apostolski likovi naslikani su samo s knjigom u ruci, a budući da nisu prikazani po redu izbora ${ }^{130}$ njihova je atribucija otežana. Položaji prepoznatljivih likova sv. Petra i sv. Pavla, te sv. Bartola $i$ sv. Jakova starijeg ključni su za odgonetavanje rasporeda preostalih apostola.

Redoslijed apostola slijedio je kalendar njihova svetkovanja: istočno od prozorske niše na sjeveroistočnom (čelnom) zidu svetišta bili su prikazani apostoli Filip i Jakov mlađi. Sv. Filipu u srednjem vijeku blagdan je bio 1 . svibnja, ${ }^{131}$ a sv. Jakovu mlađem 3. svibnja. ${ }^{132}$ Sjeverno od te prozorske niše apostoli Petar i Pavao,

${ }^{127}$ Klaić, Nada (1982.), str. 141. - Ukrasna traka s motivom stiliziranog ljiljana (fleur-de-lis), na spojevima svoda i luneta i na rubovima trijumfalnog luka, simbolizira Blaženu Djevicu Mariju. Ljiljan je simbol djevičanstva i čistoće, no, istodobno fleur-de-lis simbolizira i kraljevsku čast. Jesu li Celjski tu simboliku u kapeli sv. Petra u Novom Mjestu iskoristili ne bi li istaknuli svoje uzvišenje na kneževski položaj?

${ }^{128}$ Klaić, Vjekoslav (1974.), Povijest Hrvata, 3. Zagreb, 1974, str. 145.

129 Biblija, Stari zavjet. Povijesne knjige. Tobija. - Roman martyrology. http://www.documentacatholicaomnia.eu/03d/1856-1856, Absens, Vetus Martyrologium Romanum, LT.pdf (23.11.2017.).

${ }^{130}$ Novi zavjet, Evanđelje po Mateju, 3:18-22, 10:2-4.

${ }^{131}$ Voragine, Jacobus de, (1995.), I., 65. ( 267. - 268.).

${ }^{132}$ Voragine, Jacobus de, (1995.), I., 67. (269. - 277.). 
blagdan im je 29. lipnja. ${ }^{133}$ Dvojica apostola s istočne strane prozora na jugoistočnom zidu su apostoli sv. Jakov stariji, koji se svetkuje 25. srpnja ${ }^{134}$ i sv. Bartol kojemu je blagdan 24 . kolovoza. ${ }^{135}$ Južno od prozorske niše na jugoistočnom zidu, slijede apostoli $s v$. Matej kojemu je blagdan 21 rujna $^{136}$ i Šimun Kanaanac koji se svetkuje skupa s Judom Tadejom 28. listopada. ${ }^{137}$ Prvi u nizu na sjeverozapadnom zidu je relativno dobro očuvani lik apostola Jude Tadeja, a do njega je slijedio danas gotovo posve uništeni lik apostola Andrije kojemu je blagdan 30. studenog. ${ }^{138}$ Od posljednja dva apostola prvi je posve uništen i prikazivao je apostola Tomu koji se u srednjem vijeku svetkovao 21. prosinca, ${ }^{139}$ a mladoliki apostol na spoju s sjeveroistočnim zidom je Ivan, koji se svetkuje 27. prosinca. ${ }^{140}$

\section{Petar Bisaški (Petrus filii Georgii de Bykznad)}

Nakon smrti Ulrika II. Celjskog, Petar Bisaški i Hening Černin bili su poslanici (nuncii) slavonskog plemstva pred kraljem Ladislavom Posthumusom, pred kojim su tražili da se ukinu nezakonitosti koje je uveo Ulrik II. Kralj im je udovoljio poveljom od 24. veljače $1457 .{ }^{141}$

Istoga dana Margareta, udovica Jurja iz Novog Mjesta (viduam Georgii de Wyhel) traži uvođenje u posjede u Križevačkoj i Zagrebačkoj županiji, među kojima je Novo Mjesto. ${ }^{142} \mathrm{U}$ tražene posjede je uvedena potkraj ožujka iste godine. ${ }^{143}$

Početkom svibnja 1457. sinovi Jurja Bisaškoga (Georgii de Bykzaad), svećenik Martin i kapelan Petar žale se kralju Ladislavu da je nakon smrti Ulrika II. srpski despot Lazar otuđio posjed Rakovec. ${ }^{144}$ Petar se kasnije oženio Sofijom (Sophia, vidua Petri de Bykzad ${ }^{145}$ ), no, budući da nisu imali nasljednika svoje posjede još

\footnotetext{
${ }^{133}$ Voragine, Jacobus de, (1995.), I, 89. (340. - 350.) i 90. ( 350. - 364.).

${ }^{134}$ Voragine, Jacobus de, (1995.), II, 99. ( 3. - 10.).

${ }^{135}$ Voragine, Jacobus de, (1995.), II, 123. ( 109. - 116.).

${ }^{136}$ Voragine, Jacobus de, (1995.), II, 140. ( 183. - 188.).

${ }^{137}$ Voragine, Jacobus de, (1995.), II, 159. ( 260. - 265.).

${ }^{138}$ Voragine, Jacobus de, (1995.), I, 2. ( 13. - 21.).

${ }^{139}$ Voragine, Jacobus de, (1995.), I, 5. ( 29. - 35.).

${ }^{140}$ Voragine, Jacobus de, (1995.), I, 9. ( 50. - 55.).

${ }^{141}$ Kukuljević Sakcinski, Ivan, (1861.), Jura regni Croatiae, Dalmatiae \& Slavoniae, I. Zagabriae, 1861., str. 202-203. - Klaić, Vjekoslav (1974.), Povijest Hrvata III. Zagreb 1974., str. 343.

${ }^{142}$ Stipišić, Jakov i Šamšalović, Miljen (1960.), str. 586. (2336 D-XIII-6). - „... in possessione Wyhel in comitatu Crisiensi et possessionum Chehy, Zapredya, Ebrcs, Bothyncz ultra fluvium Zawae in comitatu Zagrabiensi introducat..."

${ }^{143}$ Stipišić, Jakov i Šamšalović, Miljen, (1960.), str. 586. (2342 D-XIII-6).

${ }^{144}$ Stipišić, Jakov i Šamšalović, Miljen, (1960.), str. 586. (2344 D-XIH-7).

${ }^{145}$ Stipišić, Jakov i Šamšalović, Miljen, (1960.), str. 621. (2858 I d 12, e!cn. IV, p. 25.) i str.622 (2871 Id 12, elen. IV, p. 24).
} 
je godine 1474. oporučno ostavio sestri Ani koja je u to doba već bila udovica (vidua Nicolai Castellan de Zenthlelek). ${ }^{146}$

Petru Bisaškome je Novo Mjesto pripalo nakon smrti Margarete (viduam Georgii de Wyhel), posljednje pripadnice ogranka Rakovečkih u Novom Mjestu, nakon 1457., a svakako prije godine 1474. U tamošnjoj crkvi Petra Bisaškoga dočekale su oštećene zidne slike na svodu, pa njihov popravak koristi da bi na najvidljivijem mjestu u svetištu dao naslikati redovnika-mučenika. Istočno od prozorske niše na sjeveroistočnom zidu svetišta, na izvornom mjestu apostola Filipa, na novom žbukanom sloju naslikan je svetac s tonzurom, u smeđoj tunici ogrnut sivim ogrtačem, palminom granom u desnoj ruci i rotulusom s izbrisanim natpisom u lijevoj. Desno (istočno) od njega istodobno je od ruke drugog slikara naslikan još jedan lik - apostol koji je nedostajao nakon umetanja sveca s tonzurom (crtež $\boldsymbol{V}$.). Osim bijelog škapulara ${ }^{147}$ ostale boje svečeva habita atipične su za dominikanski red: zbunjujuća je sivkasta umjesto crne boje ogrtača (capa magna $)^{148}$ i smeđe-crvenkasta umjesto bijele boje tunike. Je li i riječ o umjetničkoj slobodi? Slabo je poznato da je u Srednjem vijeku postojala određena sloboda u izboru oblika i boja odjeće koju su dominikanci nosili, ${ }^{149}$ a jednako tako slabo je poznato i da su u liturgiji dominikanci umjesto crne rabili i ljubičastu boju. ${ }^{150}$

Od sredine prve polovice 15. stoljeća sv. Petar mučenik ne prikazuje se više s oružjem svoga mučeništva (mač, nož, sjekira) i glave oblivene krvlju, nego s palminom granom, simbolom svoga mučeništva u desnoj ruci i knjigom u lijevoj

${ }^{146}$ Ana, kćer Jurja Bisaškoga spominje se kao udovica još godine 1470. i 1471. - Stipišić, Jakov i Šamšalović, Miljen, (1960.), str. 610 (2699 D-XV-34); str. 613. (2709 D-XV-45).

147 „The scapular was given to Blessed Reginald of Orleans by the Virgin Mary for him to pass on to Saint Dominic. The scapular was traditionally the most important article of the habit, signifying one as definitively a member of an order “. Our habits. https://friarmyke.files.wordpress. com/2011/10/our-habit2.pdf (22.2.2017.)

$148, \ldots$... because we are human, struggling with sin, lays the cappa magna symbolizing necessary penance. The black cappa magna was part of the original Dominican habit given to Blessed Reginald of Orleans." Our habits. https://friarmyke.files.wordpress.com/2011/10/our-habit2.pdf (22.2.2017)

149 „Hinnebusch notes that in the Middle Ages “shades and colours varied from province to province, even from house to house". There is then notable freedom in the use of the habit." Our habits. https://friarmyke.files.wordpress.com/2011/10/our-habit2.pdf (22.2.2017)

${ }^{150}$ Thompson, Augustine (2012.), Liturgical Colors in the Dominican Rite. - "Violet may be used in place of black." This odd provision speaks to a thirteenth-century development underway in Humbert's time. Innocent III forty years earlier had spoken of the liturgical colors as only "white, red, green, and black." But he mentions that violet has come into use in certain places. This Dominican rubric seems to reflect that older practice of using black not only for Requiems, but also on all other penitential days. So the friars had the option of conforming to the local use of violet during Lent, Advent, and Ember Days, where this had happened, but the assumption was they were still using black on those days as Innocent had considered normal." http://www.newliturgicalmovement. org/2012/07/liturgical-colors-in-dominican-rite.html\#.WMuDlGddE5s (pristupljeno 22.2.2017) 


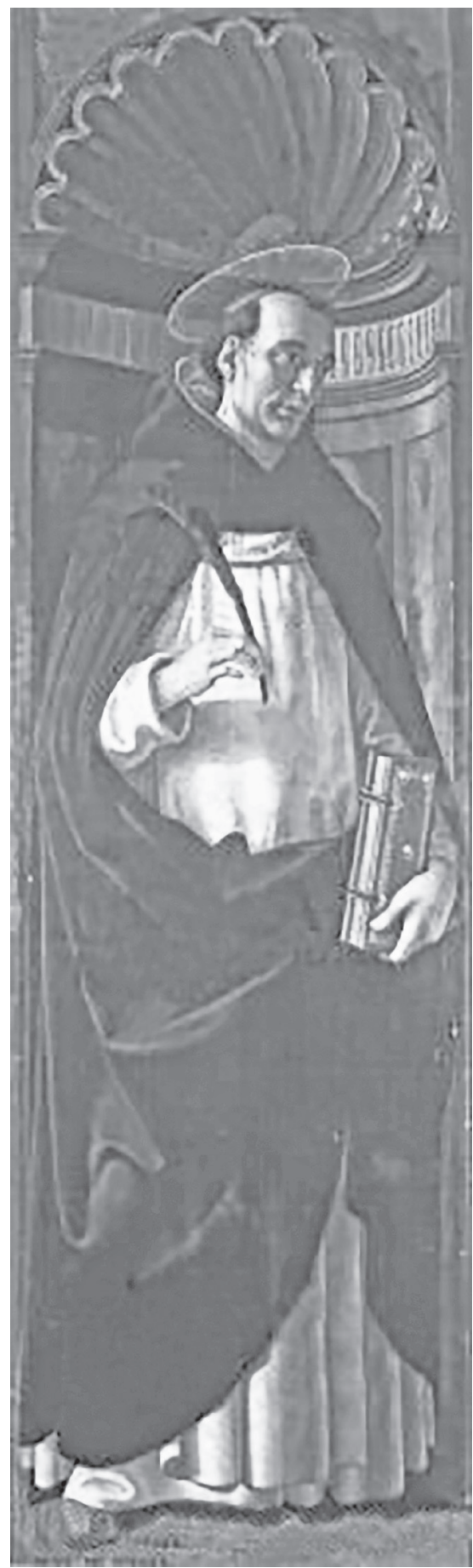

Sl. 8. Ghirlandaio, La Pala Tornabuoni - San Pietro martire. [Ghirlandaio, La Pala Tornabuoni. https:// it.wikipedia.org/wiki/Pala_Tornabuoni (pristupljeno 26.12.2017.)]

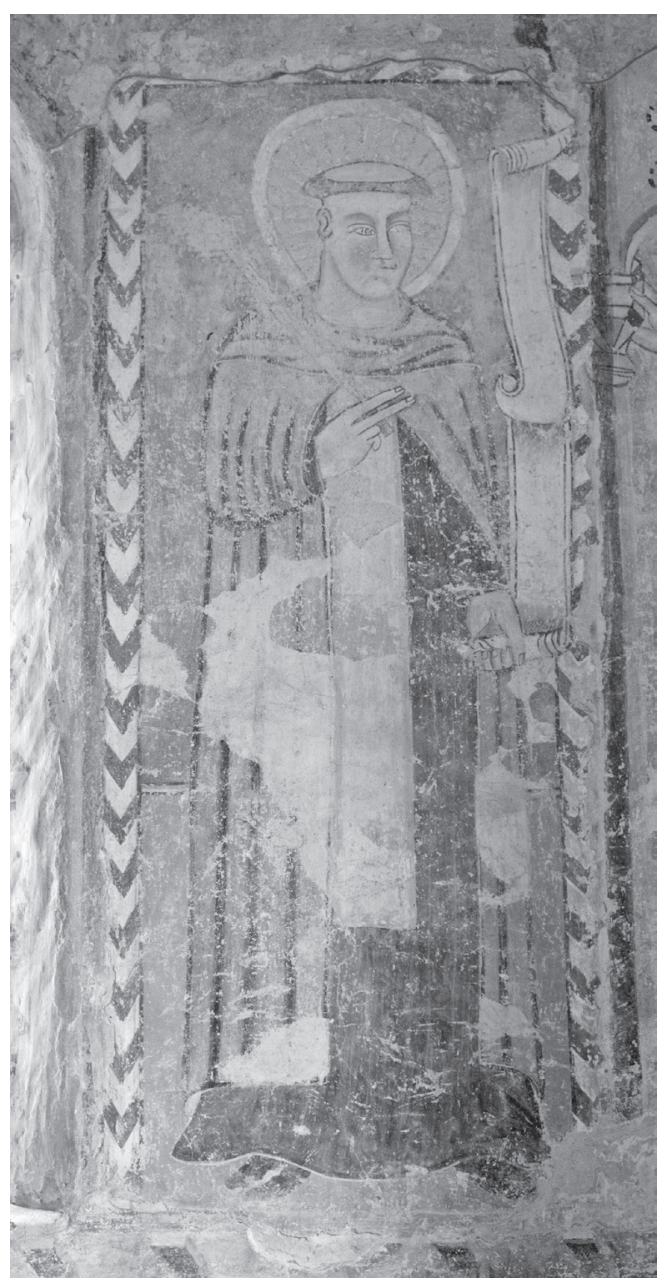

Sl. 9. Novo Mjesto, kapela sv. Petra - sjeveroistočni zid u svetištu - Sv. Petar mučenik (foto: Ivan Srša) 
ruci. Umjesto knjige u Novom Mjestu svetac u lijevoj ruci drži rotulus s uništenim natpisom, s obzirom na njegovu veličinu može se pretpostaviti da je na njemu pisalo: Credo in unum Deo. ${ }^{151}$

Imajući u vidu izvorni titular kapele prvi put spomenut godine 1381. (ecclesiam sancti Petri martiris), može se zaključiti da je naslikani lik dominikanski redovnik sv. Petar mučenik (sl. 8. i 9.), te da je po svoj prilici bio svetac-zaštitnik Petra Bisaškoga, tadašnjeg vlasnika Novog Mjesta. Slikanjem odmah do istočne stranice prozorske niše Sv. Petar mučenik kalendarski se uklopio među redoslijed apostola: njegovo svetkovanje (29. travnja) prethodi blagdanu $s v$. Filipa (1. svibnja) i blagdanu sv. Jakova mlađeg (3. svibnja).

Petar Bisaški umro je tijekom siječnja 1478., a već 8 . veljače vodi se spor oko posjeda: Bisag, Novo Mjesto, Sveti Petar, Sveta Klara i Bedenica. ${ }^{152}$

\section{POKROVITELJ OBNOVE POTKRAJ 15. I POČETKOM 16. STOLJEĆA}

\section{Juraj II. Kaštelanović (Georgius Kastellanffy)}

Tijekom konzervatorskih istraživanja zidova otkrivene su duboke pukotine $\mathrm{u}$ strukturi jugoistočnog i sjeverozapadnog zida broda, od konzola o koje su se upirali lukovi izvorne empore sve do stropa, ispunjene istom žbukom koja je poslužila i kao nosilac za kasnije djelomično oslikavanje broda i trijumfalnog luka. To je otkriće dovelo do zaključka da je približno dvjesto godina nakon utemeljenja crkva sv. Petra u Novom Mjestu znatnije oštećena u potresu.

U siječnju 1478. Petar Bisaški navodi da je stanovništvo Novog Mjesta mnogo patilo zbog Turaka (Petrus Bykzaad obiigationes incolarum possessionis suae Wyhel, qui a Turcis multa passi sunt,...), ${ }^{153}$ ali ne spominje potres. Do potresa je moglo doći ili između 1478. i 1502., ili godine 1502. kad su Zagreb i velik dio sjeverne Hrvatske stradali u snažnom potresu: velik potres v Hervatskom Orsagu

${ }^{151}$ Prema jednoj verziji sv. Petar mučenik je svojom krvlju na samrti napisao Credo (Vjerujem), prema drugoj Credo in Deum (Vjerujem u Boga), a prema trećoj Credo in unum Deum (Vjerujem $u$ jednoga Boga). Pored toga spominje se i da je tijekom mučeništva izgovorio: In manus tuas, Domine, commendo spiritum meum (U ruke tvoje Gospodine predajem duh svoj). Na osnovu izvora i analize zadobivenih rana na svečevoj lubanji Donald Prudlo zaključio je da zasigurno nije mogao napisati ni jednu od navedenih rečenica, te da je najvjerojatnije tek započeo moliti Apostolsko vjerovanje (Credo). - Prudlo, Donald (2008.) The Martyrdrom Inquistor: The Life and Cult of Peter of Verona (martyred 1252.). Hampshire, 2008. str. 65. - Google books. https://books.google.hr/

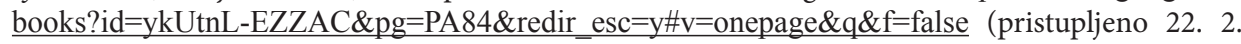
2017.)

${ }^{152}$ Stipišić, Jakov i Šamšalović, Miljen (1960.), str. 621. (2856 D-XVI-22)

${ }^{153}$ Stipišić, Jakov i Šamšalović, Miljen (1960.), str. 621. (2853 D-XVI-71) 
od koga se vnoge hishe porussise, i v Zagrebu turren S. Marka ${ }^{154} \mathrm{U}$ to doba vlasnik Novog Mjesta i Bisaga bio je Juraj II, sin Nikole Kaštelanovića i Anne Bykzaad, sestre Petra Bisaškoga.

Prilikom otklanjanja šteta uzrokovanih potresom odstranjena je zidana empora koja je konzolama bila uprta u jugoistočni i sjeverozapadni zid broda. Nakon obnove djelomice su nanovo oslikani zapadna strana trijumfalnog luka $i$ istočni dijelovi bočnih zidova broda. Oveći fragment oslikavanja trijumfalnog luka sačuvan je sjeverno od njegova otvora: na grubom vapnenom premazu s vidljivim širokim potezima četke, in secco je naslikana znatno izblijedjela ali zato vješto slikana scena Raspeća s Marijom i Ivanom pod križem. Neposredno do trijumfalnog luka i scene Raspeća na sjeverozapadnom zidu broda nazire se izblijedjela velika kompozicija Posljednjeg suda. U vrhu scene prikazan je "Krist na prijestolju" (Apokaliptički sudac), ${ }^{155}$ ispod njega arkanđeo Mihael. S promatračeve desne strane mrtvi ustaju iz grobova, a s lijeve sv. Petar stoji pred vratima Nebeskog Jeruzalema.

\section{ZAKLJUČAK}

Među srednjovjekovnim crkvama i kapelama u kontinentalnoj Hrvatskoj malo ih je koje su tijekom dva stoljeća bile toliko puta obnavljane i oslikavane kao kapela sv. Petra u Novom Mjestu. Od šest fragmentarno sačuvanih slojeva zidnih slika, nastalih tijekom 14., 15. i početka 16 . stoljeća, prvi, drugi i četvrti sloj predstavljaju velike, a ostali manje zahvate sačuvane na zidovima kapele. Prva tri sloja na trijumfalnom luku i zidovima u brodu i peti slikani sloj nastali su u doba kad je Novo Mjesto posjedovala plemićke obitelj Rakovečki odnosno njezin bisaški ogranak, četvrti sloj može se datirati u doba grofova Celjskih, a šesti sloj pripada dobu Kaštelanovića.

Među scenama na zidovima kapele sv. Petra teško oštećeni prizor Sveto lice iz Luccae u sjeverozapadnoj luneti svetišta temom je nedvojbeno unikatna u zidnom slikarstvu srednjovjekovne Slavonije, jednako kao što su to i fragmenti legende o Svetom Ladislavu na sjeverozapadnom zidu broda. ${ }^{156}$ Pored tih izrazito fragmentiranih scena cjelovitije su očuvani prizori na lučnom dijelu trijumfalnog

\footnotetext{
${ }^{154}$ Kišpatić, Mišo, Potresi u Hrvatskoj. Zagreb, Zagreb, 1981. str. 16.

${ }^{155}$ Fučić, Branko, (1979.) Posljednji sud, str. 478. i 611.: „U XV. stoljeću iz usta mu izlazi mač prema strani osuđenih, a ljiljan prema strani blaženih."

${ }^{156}$ Neznatni fragmenti te scene sačuvani su i na južnom pročelju crkve sv. Augustina u Velikoj (Požeška biskupija).
} 
luka s temom Jeseova stabla kao i scena Majke milosrđa južno od njegova otvora, te više apostola u svetištu.

Premda znatnije oštećeni i bez sačuvanih lica vrijedni su i detalji dvojice pokrovitelja oslikavanja na zapadnoj strani trijumfalnog luka, oba sačuvana sjeverno od njegova otvora. Donator naslikan u drugom registru, koji kleči s ključem u desnoj i lancem u lijevoj ruci - pred visokim likom odjevenim u bijelo, prije nalik haljini Uskrslog Krista negoli redovničkom (dominikanskom) habitu - vjerojatno je prikazivao Ladislava Rakovečkog, utemeljitelja kapele u Novom Mjestu. Lik donatora koji kleči ispred svetog Emerika, u naknadno unesenoj sceni u trećem registru, po svoj prilici prikazuje Emerika Bisaškog.

Napomena: Fotografije i crteži vlasništvo su HRZ. Ilustracije broj 6. i 8. skinute su s interneta.

${ }^{\star}$ Bolzano, Chiesa dei domenicani. http://www.bolzano.net/it/chiesa-domenicani.html (pristupljeno 26.12.2017.)

** Ghirlandaio, La Pala Tornabuoni. https://it.wikipedia.org/wiki/Pala Tornabuoni (pristupljeno 26.12.2017.) 


\section{ST PETER'S CHAPEL AT NOVO MJESTO}

(Twenty years later)

By Ivan Srša, Zagreb

\section{Summary}

The paper elaborates on the first two centuries of Novo Mjesto's history, the chapel and its patrons dating from the chapel's establishment to the restauration at the beginning of the 16 th century (1302 - 1502). The time of the chapel's establishment is determined on basis of longitudinal axis azimuths estimated on basis of geodesic measurements (from the shrine to the nave axis). The chapel's sacred orientation and its original titular lead to the conclusion that the church had been established in 1302 and dedicated to the Dominican friar St Peter Martyr. St Peter's chapel was established in the period of Ladislav Rakovecki who had the north-west nave wall painted with scenes from the Legende o sv. Ladislavu (Legends about St Ladislav), dedicated to his protector. There are also several layers of mural paintings from the $14^{\text {th }}, 15^{\text {th }}$ and $16^{\text {th }}$ centuries preserved in fragments, among which the most valuable are the scenes Mother of Mercy and Tree of Jesse on the triumphal arch, and Holy Face of Lucca and apostles on the shrine walls.

Key words: Novo Mjesto; St Peter's chapel; middle ages; architecture; mural paintings 